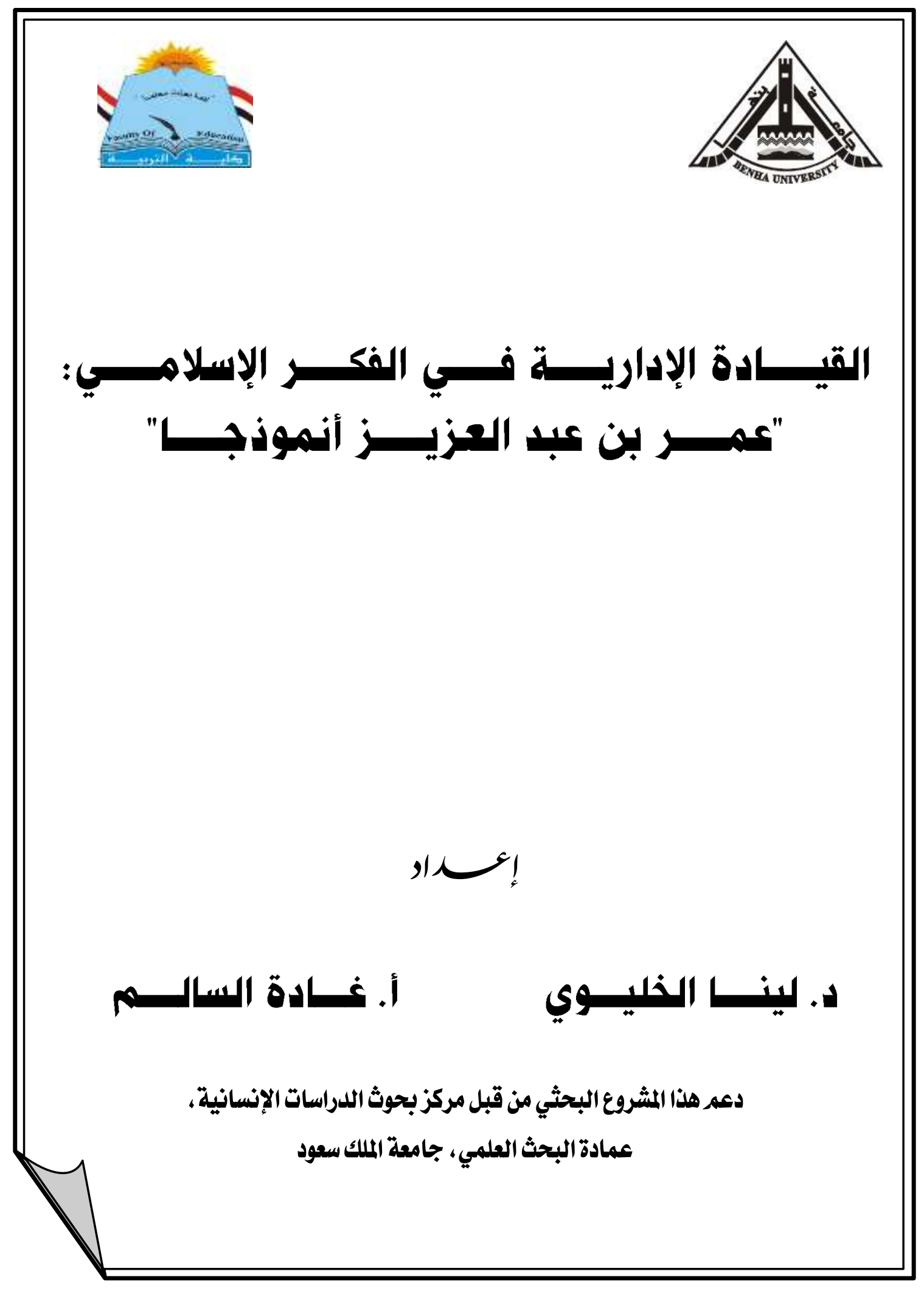




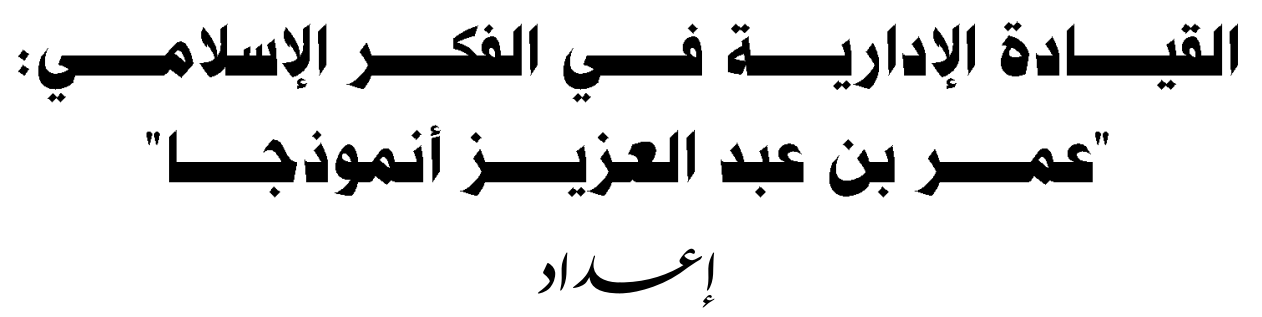

أ. غنسادة السالسـم

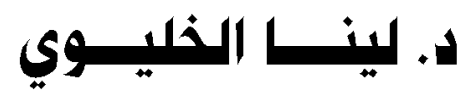

\section{ملذــص الدراســة}

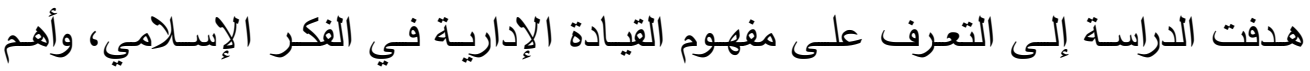

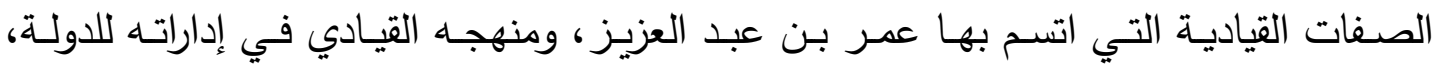

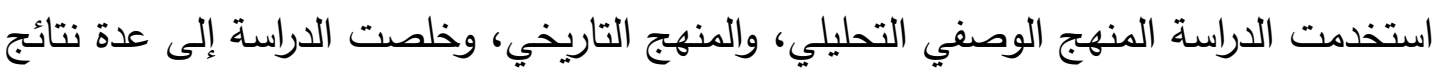
أهمها: أن القيادة الإسلامية ذات منهج رباني، وأهداف سامية، فهي تسعى للمشاركة والتتاصح وتتميز بدرجة عالية من تقبل النقد من أجل المصلحة العامة، وتعتبر شخصية عمر بن عبد

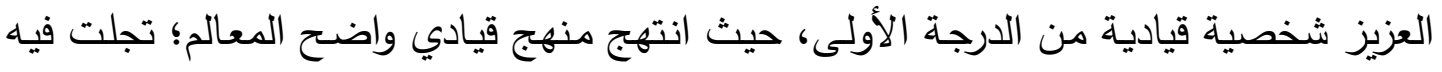

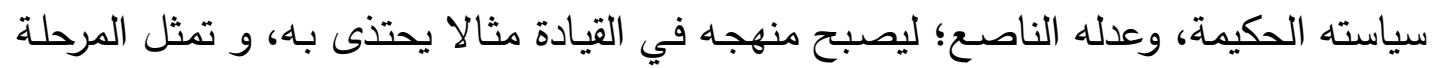
التي قضاها عمر بن عبد العزيز في الحكم فترة حضارية هامة في المجتمع الإسلامي، حيث تم

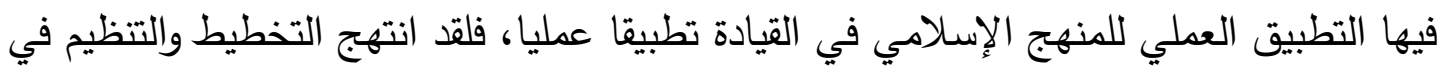

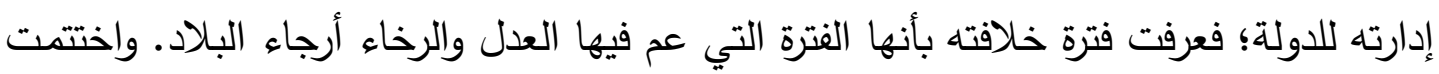

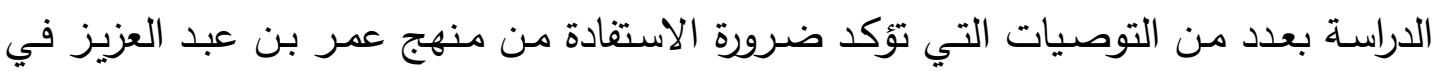
القيادة، وتطبيقاته في الإدارة التربوية.

الكلمات المفتاحية: القيادة الإدارية، عمر بن عبد العزيز. 


\section{مقدمسة الدراسيسة:}

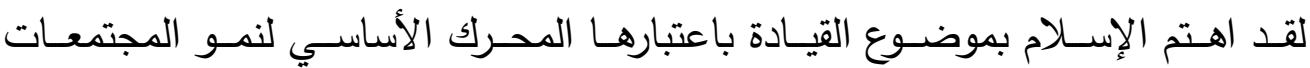
وازدهارها، فعلى مر التاريخ استطاعت العديد من الأمم بناء مجدها بفضل توفر قيادة حكيمة

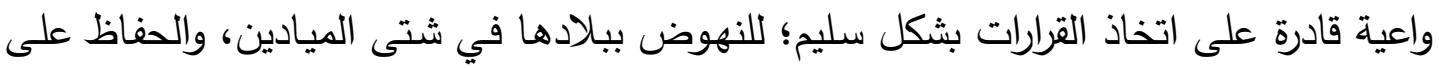
مكانتها المميزة بين باقي الأمم.

وتظل القيادة هي العامل المشترك لتقدم المجتمعات، ولقد اهتم بها الإسـلام باعتبارها

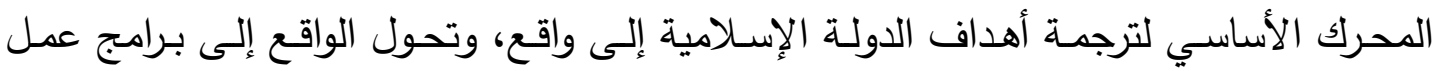

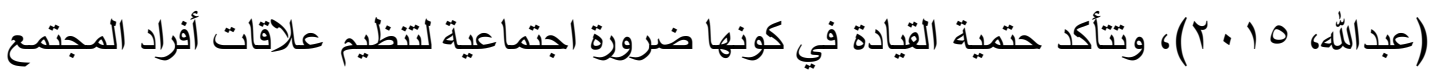
الواحد، والإسلام يحرص على النظام للجماعة، ويحث دائما على تحديد القيادة عن طريق اتفاق

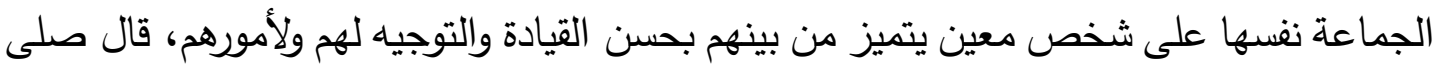

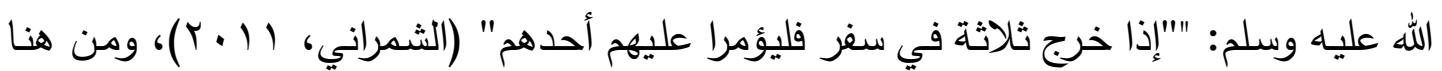

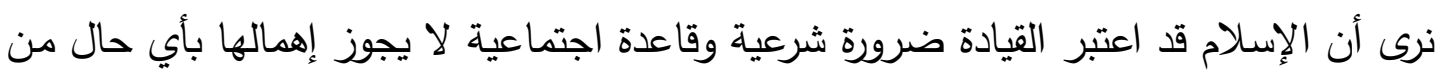

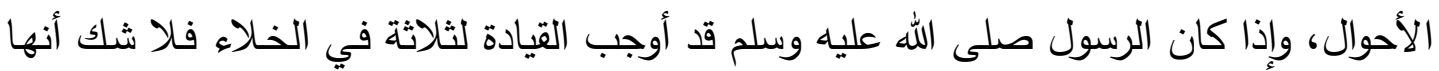

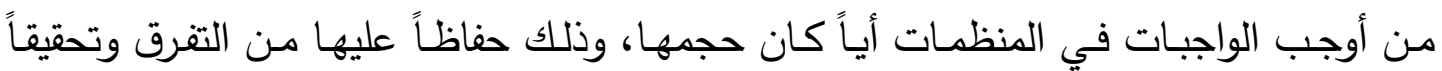

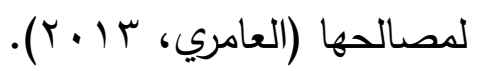

وبالنظر للتاريخ الإسلامي، نجد العديد من القادة تمكنوا من تغيير تاريخ أمتهم بأعمالهم

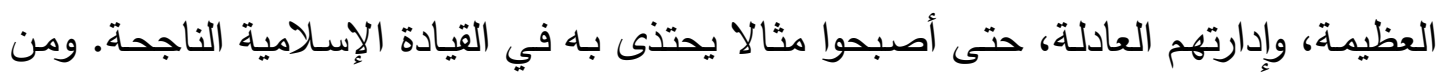

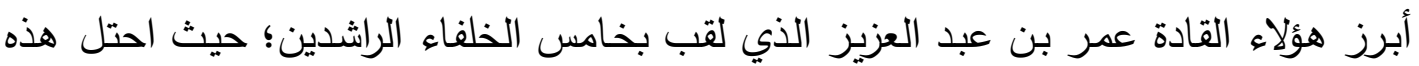

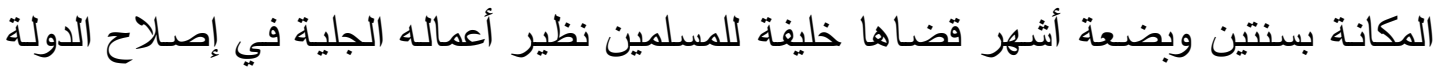
الإسلامية وإثاعة العدل والحكم بشرع الله وسنة نبيه صلى الله عليه وسلم.

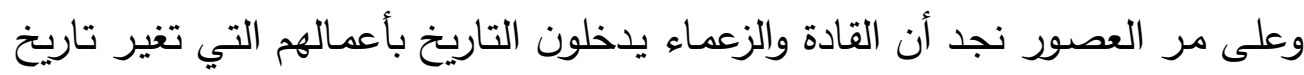

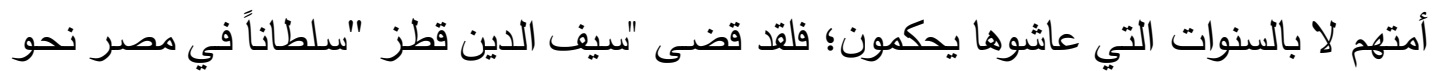

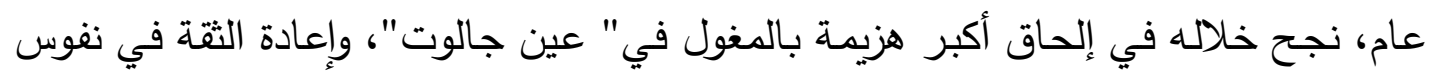

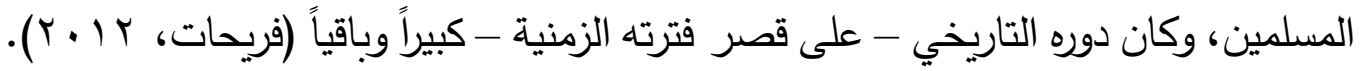

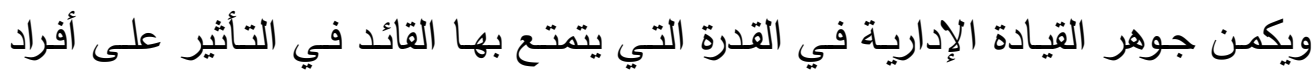

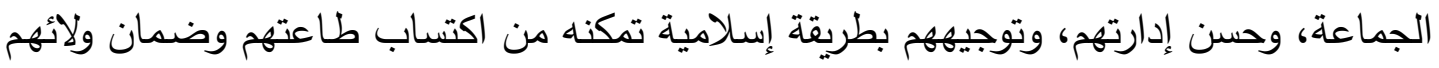

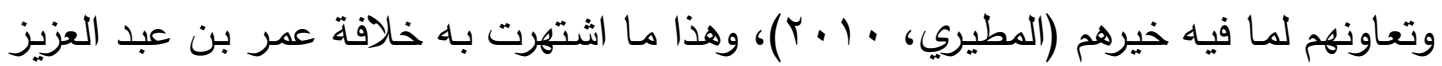
كقائد إداري محنك، استطاع في فترة وجيزة أن يبني تاريخ أمة. 


\section{مشكاستة الدراسئة:}

إن الثريعة الإسلامية من خلال مصادرها الأساسية (القرآن الكريم، والسنة النبوية) تحتم

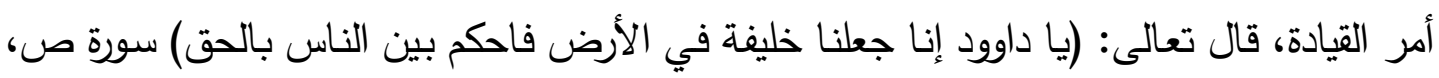

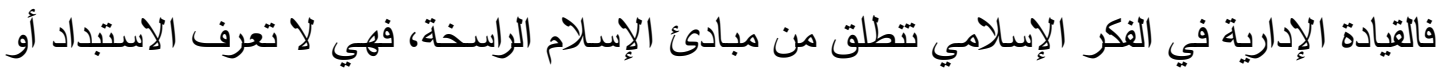
الفوضى، بل هي قيادة سوية يحكمها شرع الله وسنة نبيه صلى الله عليه وسلم.

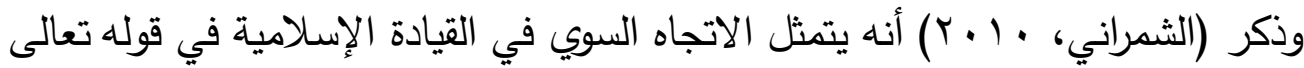
مخاطبا رسوله الكريم صلى الله عليه وسلم باعتباره قائد الأمة الإسلامية: (فبما رحمة من الله لنت

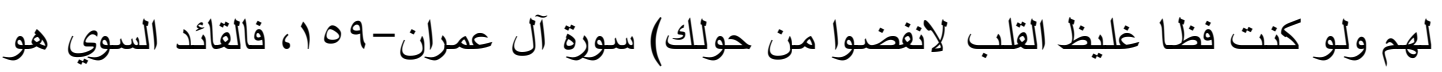
من يستطيع التأثير على الآخرين فكراً وسلوكاً.

ومن أعظم القادة الذين عرفوا بقيادتهم السوية "عمر بن عبد العزيز" الذي اشتهرت خلافته بأنها الفترة التي عم فيها العدل والرخاء في أرجاء البلاد الإسلامية، حتى أن الرجل كان

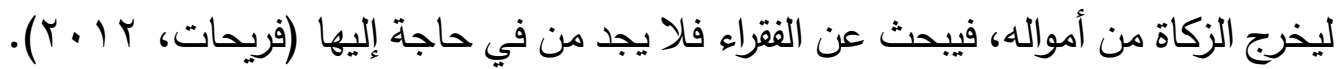
لقد كان عمر بن عبد العزيز عالما عاملا، همه كله وعزمها، إحياء السنن، ونصر صاحبها، وإماتة البدع ومحدثات الأمور ومحوها، قال عنه الحافظ ابن حجر : [ولم يسلم بتوفر جميع خصال الخير كلها في شخص واحد، إلا أن يدعى ذلك في عمر بن عبد العزيز ، فإنه كان

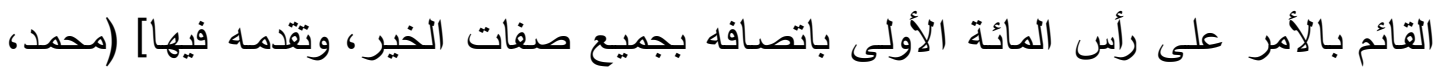

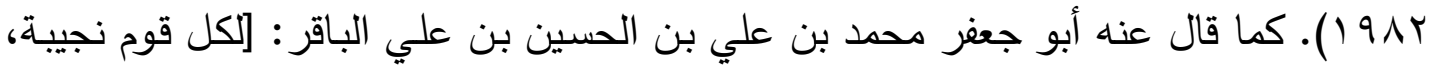

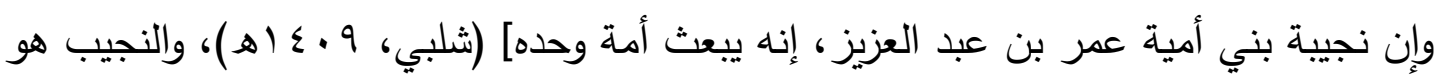

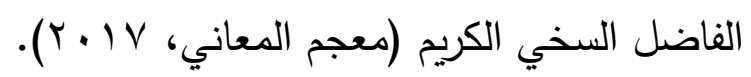

والمتتبع لأقوال العلماء والمؤرخين والمهتمين بدراسة الحركة التجديدية، يجد إجماعاً تاماً

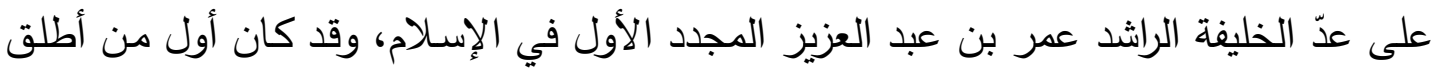

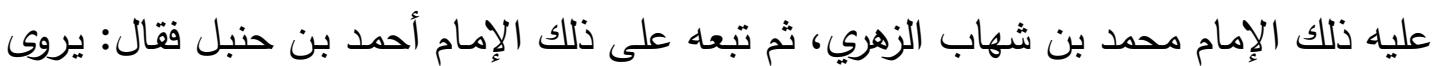

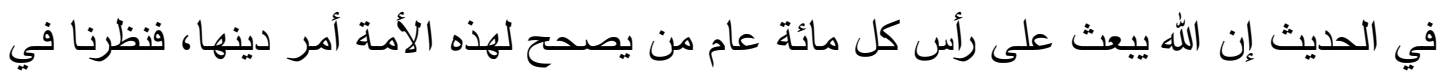

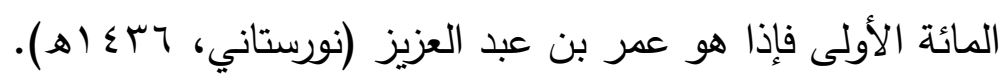

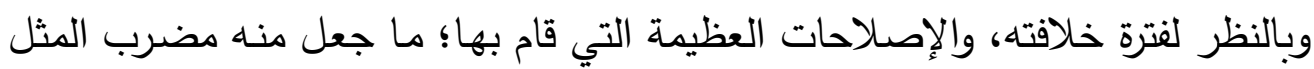
في القيادة الإدارية المحنكة، التي استطاع من خلالها إرساء دعائم الإصلاح الإداري، ليصبح 
عصر خلافته من أفضل عصور الدولة الأموية وأكثرها عدلا ورخاء. ومن خلال ما سبق، كان

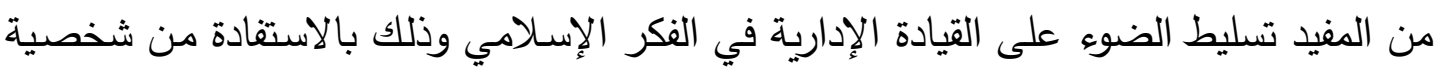
عمر بن عبد العزيز كأنموذج للقائد المسلم الناجح.

\section{أهـــافـ الدراسيسلة:}

(التعرف على مفهوم القيادة الإدارية في الفكر الإسلامي.

× التعرف على الصفات القيادية التي اتسم بها عمر بن عبد العزيز. × التعرف على منهج عمر القيادي في إداراته للدولة.

\section{أهميسية الدراسيستة:}

× تأخذ الدراسة أهميتها من خـال ما تميز به عمر بن عبد العزيز باعتباره مجدد الإسـلام

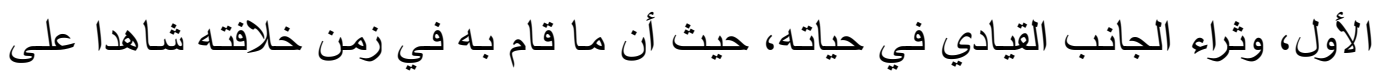

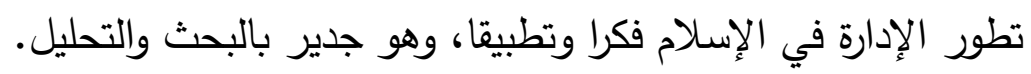
× كذلك أهميـة علم الإدارة، ومـا يتم دراسته عن المبادئ والنظريـات الثـرقية والغربيـة؛ فإن الحاجة ملحة للتعرف على المبادئ والأسس الإدارية والسمات القيادية لدى القادة المسلمين، وذلك للمساهمة في إعادة بناء واتباع النموذج الإداري في الإسلام من خـلال ما طبقه عمر الإدراته بن عبد العزيز في قيادته للدولة. × سوف تضيف هذه الدراسة عموماً إلى الأطر النظريـة في مجال الإدارة في الإسـلام من حيث رواد الفكر الإداري في الإسلام.

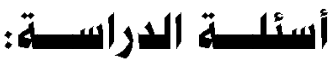
ج ما مفهوم القيادة الإدارية في الفكر الإسلامي؟ \ ما الصفات القيادية التي اتسم بها عمر بن عبد العزيز؟

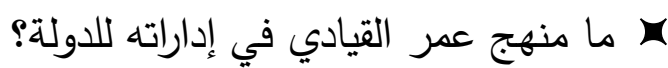

\section{هـدود الدراستسة:}

× الحـدود الموضـوعية: سيتتاول البحث موضـوع القيـادة الإداريـة في الفكر الإسـلامي، وذلك بالاستفادة من شخصية عمر بن عبد العزيز كأنموذج للقائد المسلم الناجح. الحدود المكانية: الدولة الأموية في عهد عمر بن عبد العزيز . 
×ـ الحدود الزمانية: يقتصر البحث على أهم المواقف التي تبين منهج عمر بن عبد العزيز القيادي أثناء فترة خلافته التي امتدت سنتان وخمسة أشهر ـ ولقد تم إجراء الدراسة في لفي

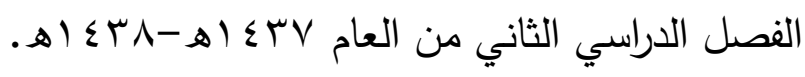

\section{مصطلحسـات الدراسهـة:}

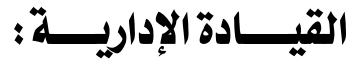

هي عملية من خلالها يؤثر فرد في مجموعة من الأفراد لتحقيق هدف مشترك (نورث

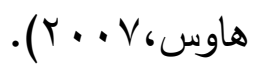

وتعرف إجرائيا: هي القدرة على التأثير في سلوك الأفراد، وتوجيههم، لتحقق المنظمة

\section{القيادة الإدارية في الفكر الإسلامي:}

كل من يتولى شيئا من أمور المسلمين العامة، فالإمام قائد، والأمير قائد، والمرأة في بيتها

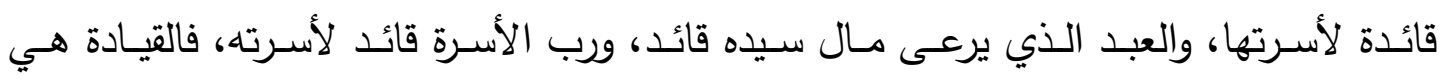

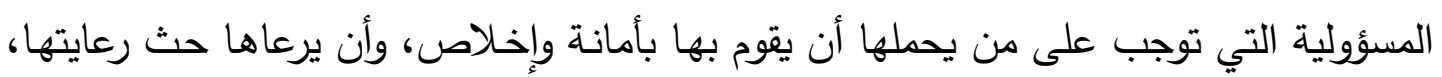

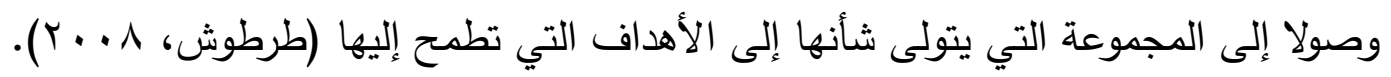

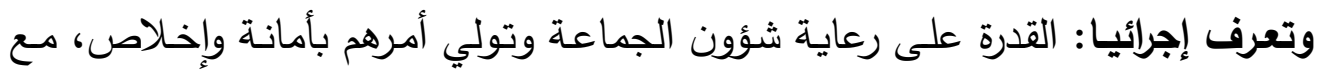
إرشادهم وتوجيههم لما فيه مصلحة الأمة.

\section{الدراســات السابة}

سيتم عرض الدراسات التي تم الرجوع إليها مع بيان أوجه الثبه والاختلاف بينها وبين

$$
\text { الدراسة الحالية، وستعرض مرتبة من الأقدم فالأحدث. }
$$

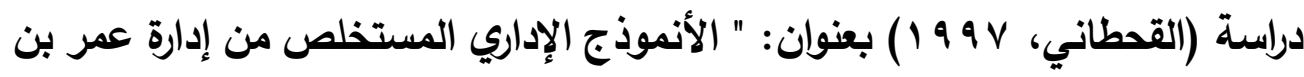
عبد العزيز وتطبيقاته في الإدارة وبخاصـة الإدارة التربويـة" هدفت الدراسة إلى إبراز النموذج الإداري الإداري الذي تميز به عمر بن عبد العزيز وتطبيقاته في الإدارة الحالية. وقد استخدمت الدراسة الداسة

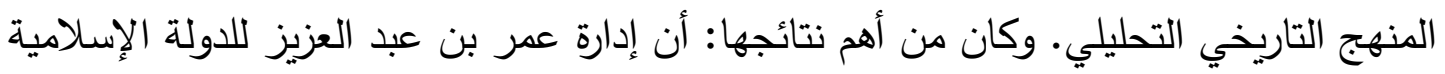
تميزت بمقصود الولاية الإسلامية، إذ جمع بين الصفات القيادية، والمبادئ الإدارية البناءة. 


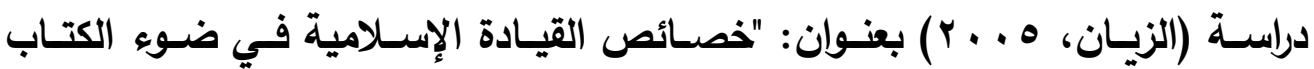
والسـنة" هدفت الدراسـة إلى التعرف على خصـائص القيادة الإسـلامية في القرآن والسنة، مـع الاستفادة من الدراسات الإدارية الحديثة. وقد استخدمت الدراسة المنهج الوصفي التحليلي. وكان من أهم النتائج: أن الإسـام اهتم بالقيادة في كل مستوياتها من قيادة الجماعة في الأسرة أو رفقاء العمل، وحتى الولاية العامة على المسلمين. دراسة (طاهر، 7 × . r) بعنوان: " القيادة التربوية في الإسـلام" هدفت الدراسة إلى التعرف على خصـائص وسـات القيـادة التربويـة في الإسـلام. وقد استخدمت الدراسـة المـنهج الاستقرائي لاستخلاص سمات وخصائص القيادة عموما، والقيادة التربويـة في ضوء المعايير الإسـلامية. وكان من أهم النتائج: من أهم سمات القيادة التربويـة في الإسـلام الإخـلاص الله، والاستعانة بـه والتوكل عليه، الاهتمام بالتخطيط وتحديد الأهداف، وبث روح التعاون والمحبة بين المرؤوسين.

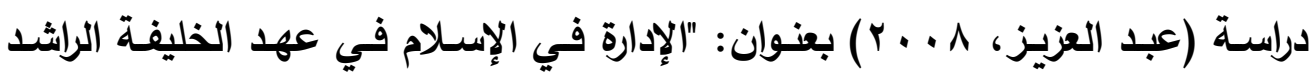
عمر بن عبد العزيزي" هدفت الدراسـة إلى إبراز ما ينبغي أن يكون عليه الحكم من واقع تجربـة عملية وليس مجرد نصوص نظريـة، من حيث إبراز الإدارة في عصر الرسول صلى الله عليه وسلم، ومن ثم الإدارة في عهد الخلفاء الراشدين أبوبكر وعمر ، وعثـان وعلي، وصولا إلى عمر

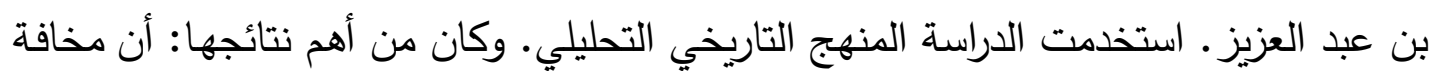
الله والتقوى والتزام شرعه أسفر عن العدل والاستقرار الذي اتسمت به إدارة عمر بن عبد العزيز .

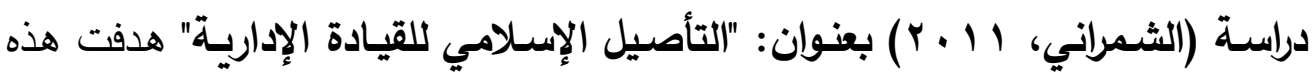
الدراسة إلى معرفة مفاهيم القيادة في الإسـلام وفي الإدارة الحديثة، والتعرف على مقومات القيادة الإسلامية ومعاييرها، والكثف عن بعض النماذج من نظريات القيادة وموقف الإسـلام منها. وقد استخدمت الدراسة المنهج الوصفي التحليلي. وكان من أبرز نتائجها: أن القيادة في الإسلام تتسم بأنها قيادة سوية وسطية لا هي متسلطة فظة ولا هي متراخية غير موجهة ولا هي ديمقراطية مطلقة في كل الأوقات، وأن هناك قيادات إسـلامية رائعة يأتي في مقدمتها الرسول صلى الله عليه وسلم وخلفاؤه الراشدين، وأن التربية الإسلامية لها دور كبير في بناء الشخصية القيادية المسلمة في كل موقع وخاصة قيادة التربية.

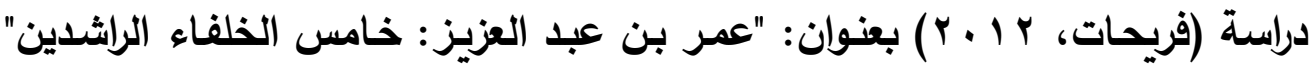
هدفت الدراسـة إلى استعراض سيرة الخليفة عمر بن عبد العزيز وسياسته الداخلية في الحكم، 
ونماذج من عدله. واستخدمت الدراسة المنهج الوصفي التاريخي. وكان من أهم النتائج: أن أهم

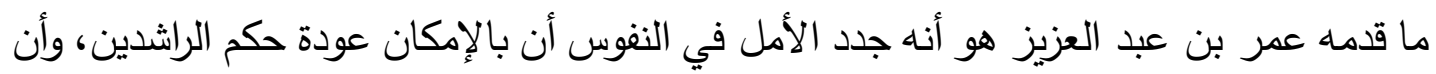

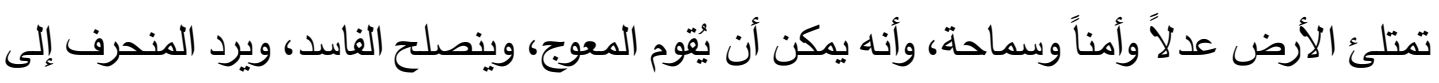
جادة الصواب، وأن تهب نسائم العدل واحترام الإنسان، إذا استشعر الحاكم مسئوليته أمام الله، وأنه الهانه مؤتمن فيما يعول ويحكم، واستعان بأهل الصلاح من ذوي الكفاءة والمقدرة.

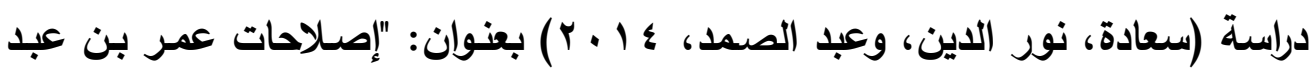

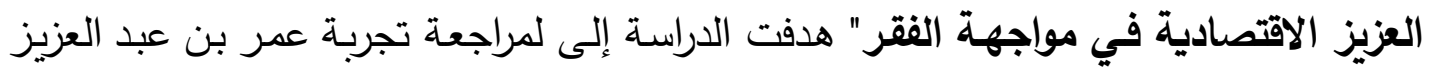

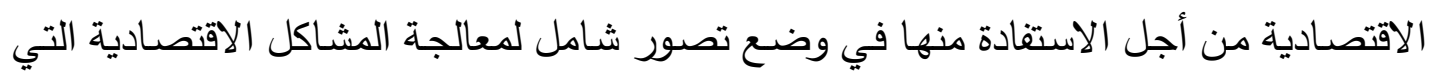

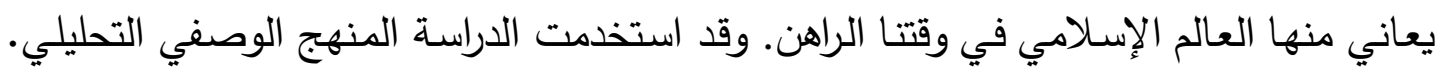

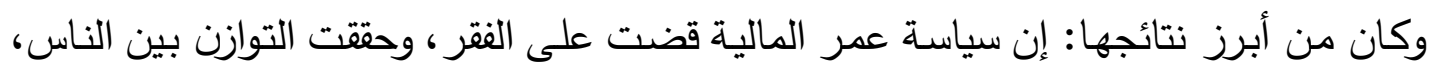

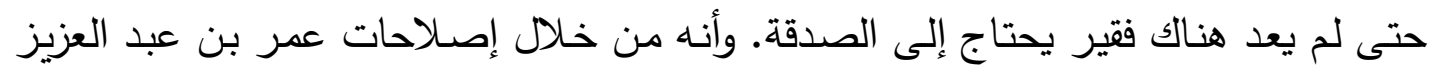
الاقتصادية الناجحة تم التوصل إلى نموذج إداري اقتصادي ناجح، نرى صلاحيته للتبني والتطبيق

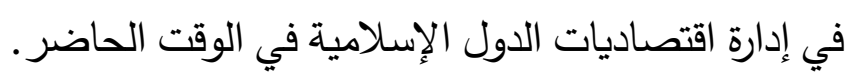
دراسة (نورستاني، ؛ 1 + ب) بعنوان: " الجوانب التربوية في حياة عمر بن عبد العزيز"

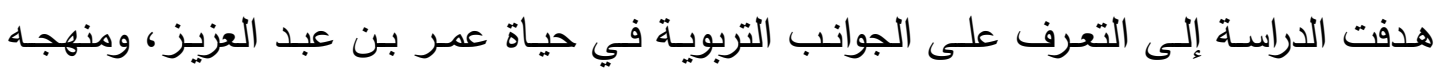

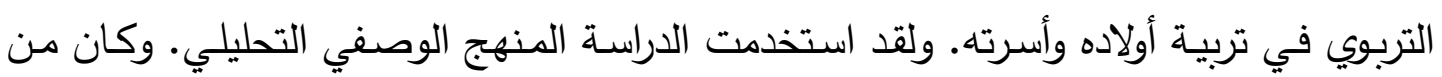

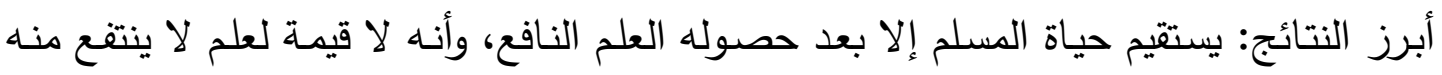

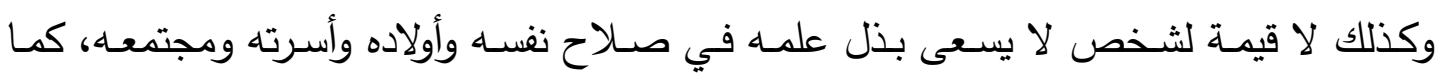
أن البيئة الاجتماعية المحيطة لها دور فعال ومهم في صناعة الرجال وبناء شخصيتهم.

\section{التعليق على الدراسات السابقة:}

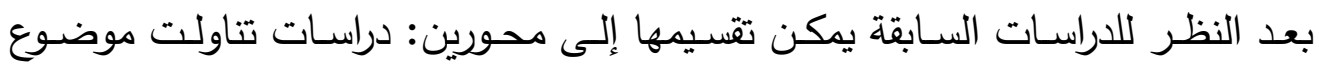

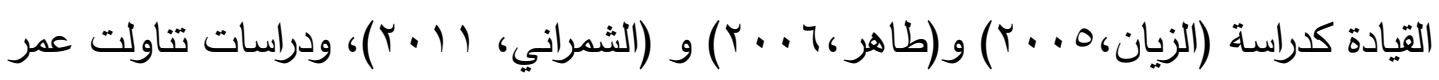

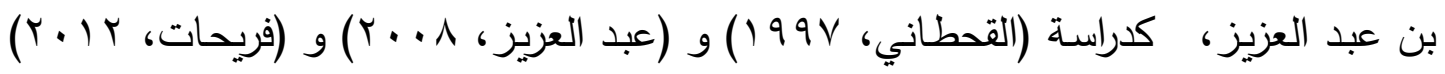

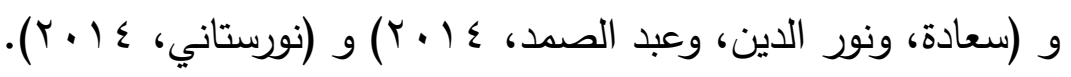

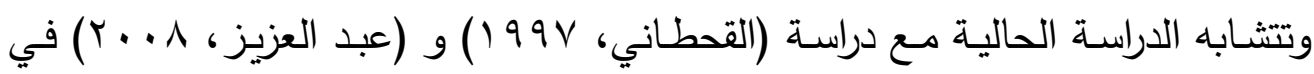
تتاولها للجوانب الإدارية في شخصية عمر بن عبد العزيز، وكذلك استخدامها للمنهج التاريخي، 
ولكن ما يميز هذه الدراسة تركيزها على موضوع القيادة الإدارية، وأهم الصفات القيادية التي

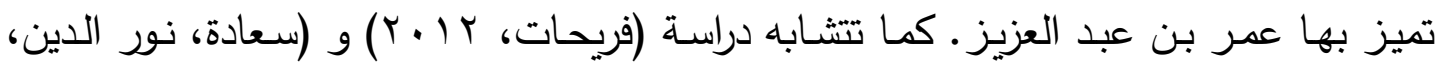

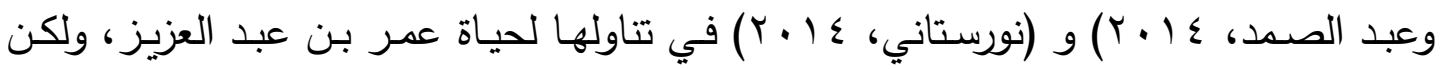

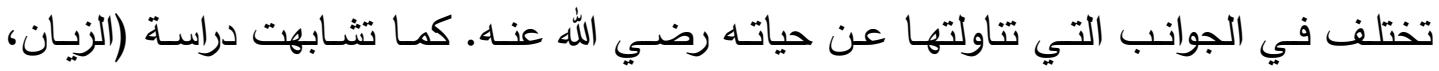

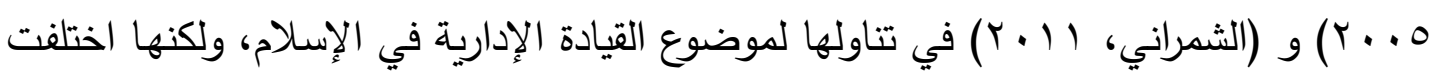

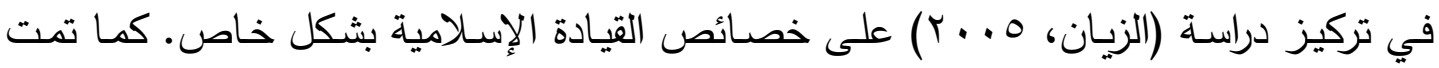
الاستفادة من الدراسات السابقة في الإطار النظري، واستخلاص النتائج والتوصيات.

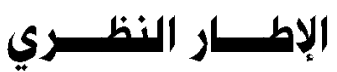

سيتم استعراض الإطار النظري ضمن مبحثين: الأول: القيادة الإدارية. الثاني: عمر بن عبد العزيز . (n)

\section{أولا: القيـــادة الإداريــــة:}

يتناول هذا المبحث مفهوم القيادة، والفرق بيم القيادة والإدارة، والمهارات التي يتمتع بها

\section{مفهـــوم القيــــادة:}

القيادة لغة: ذكر ابن دريد بأن القيادة .مأخوذة من الفعل (قاد) كما في: قاد الرجل بعيره

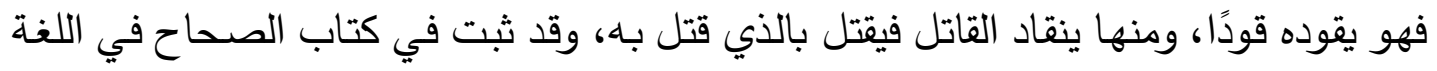

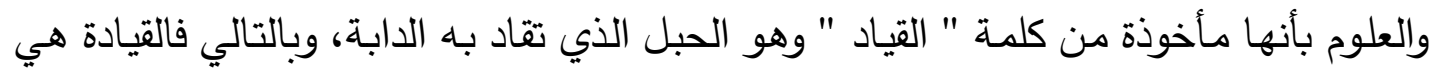

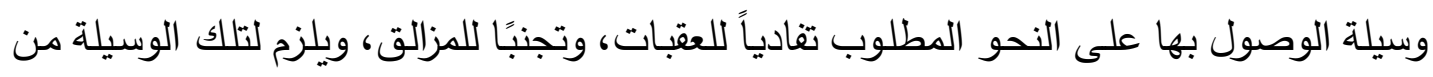

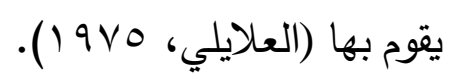

اصطلاحا: هي حالة ظرفية، لفرد يملك فطرة، وقيمًا، ومعرفة، ومهارات مقبولة اجتماعيًّا

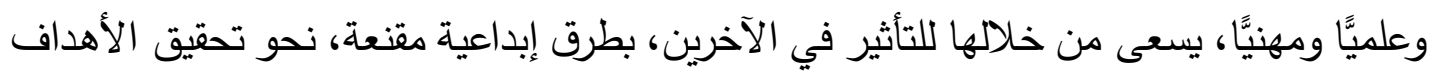

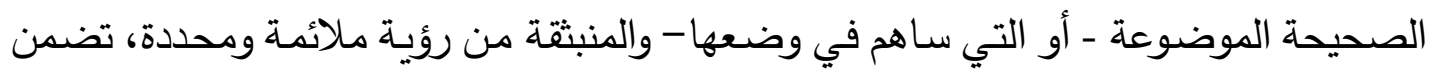

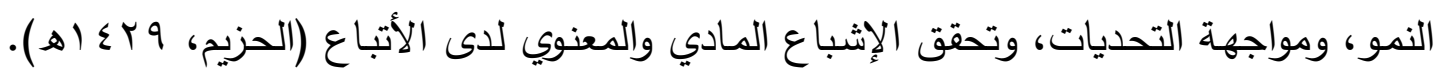

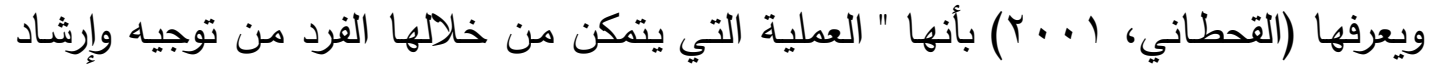

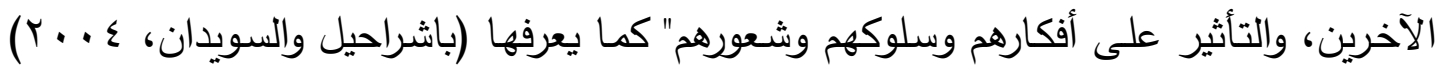

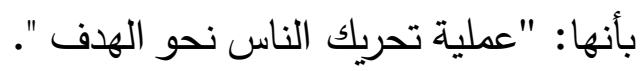


والقائد الإداري هو الذي يتحسس مطالب الجماعة التي يتعامل معها ويوجهها بمرونة،

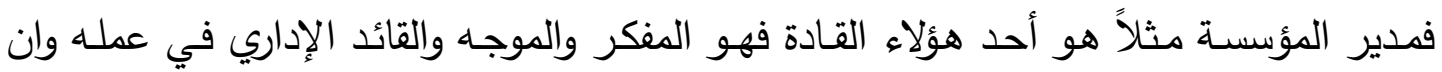
نجاح المؤسسة يتأثر إلى حد كبير بشخصيته وميوله واتجاهاته (شهاب، ب).

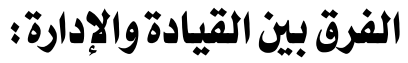

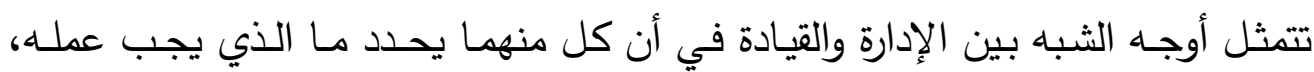

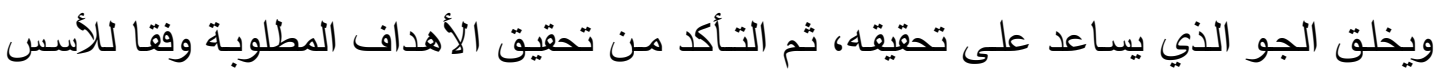

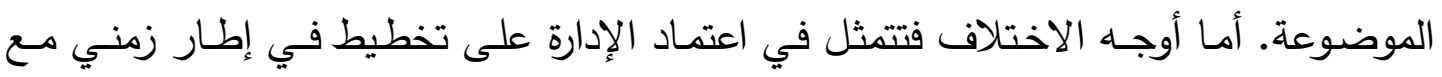

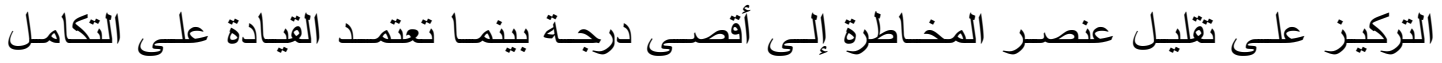

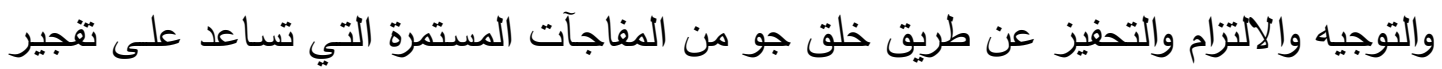

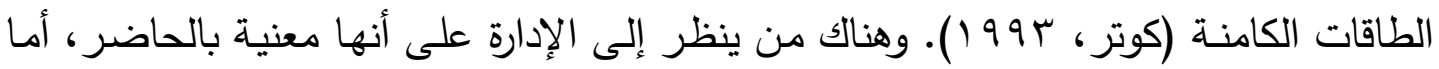

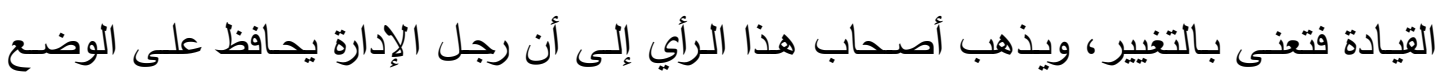
الراهن، وليس له دور في تغييره، لأنه يستخدم الوسائل والأساليب القائمة بالفعل من أجل تحقيق الإدان الأهداف أو الأغراض المقرة سلفا، أما القائد فهو داعية للتغير ومطلوب منه أن يحدث تغييرات في البناء والتنظيم (العدواني، ب د).

\section{مهـــــارات القائســـــــ}

هناك عدد من المهارات التي يتمتع بها القائد، وقد ذكرها (Yuki, 1989) كما يلي: 1-مهارة تفويض السلطة: وتعني اشتراك العاملين في أعمال الرقابة والتأثير في الآخرين، وان لهان

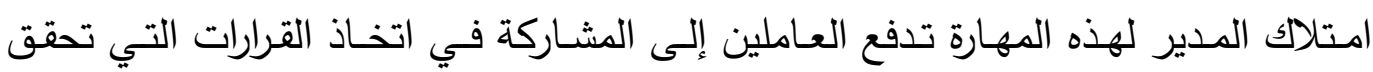
أهداف المنظمة ومن ثم دفعهم لتحمل جوانب من مسؤوليات العمل. r- مهارة الحسس: وهي القابلية على التوقع بالتغيير وتوسيع الرؤيـة المستقبلية وتبني الثقتة

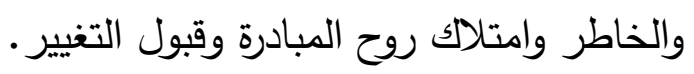

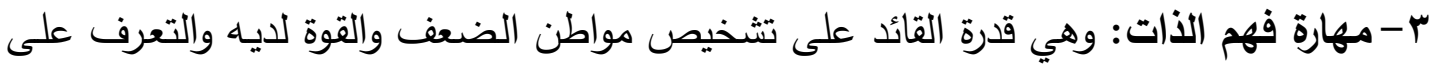
قدراته وإمكاناته واختيارها من أجل إكساب مهارات معينة.

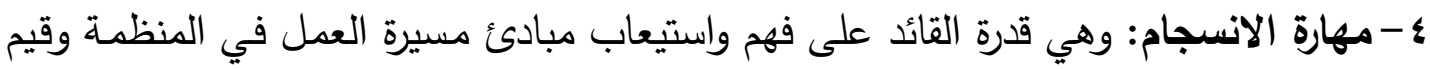
العمل وقيم العاملين وإحداث التوافق بينها من أجل الإنجاز الأفضل. 
ه- مهارة التبصر : وهي قابلية القائد على التصور والتمثيل والنظرة إلى ما وراء الحالات التي تواجها في المستقبل ليتمكن من وضع خطة عمل لمواجهة تلك الحالات.

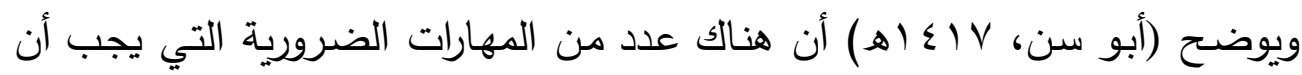

يكتسبها القائد الإداري لكي تتوفر له مقومات القيادة، وهذه المهارات:

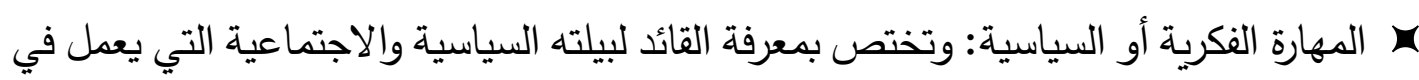

حدودها.

با المهارة الإنسانية: وتختص بمعرفة القائد للجماعة التي يعمل على قيادتها.

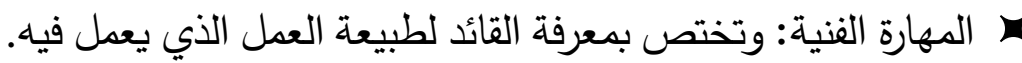

\section{واجبات القيادة في الفكر الإسلامي:}

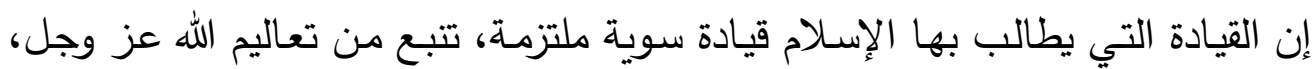
تهدف إلى التأثير في الآخرين نحو الاتجاه الذي يحقق مصالح الأمة. ولكي تحقق القيادة الغاية منها؛ يجب أن تقوم بالواجبات التالية:

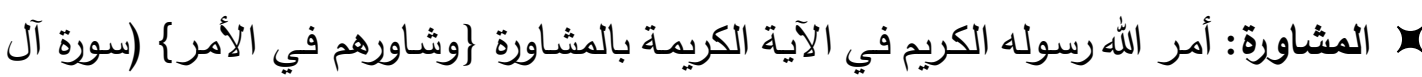

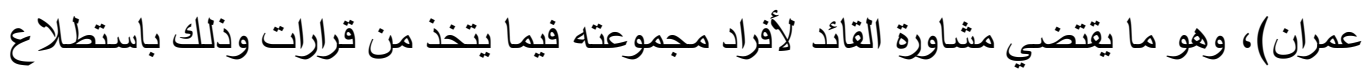

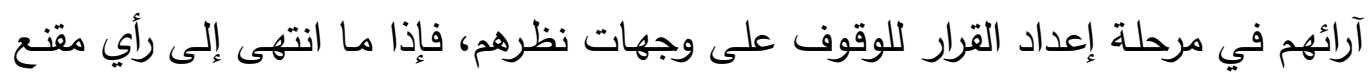
أمضاه، وأصدر قرارا على مقتضاه.

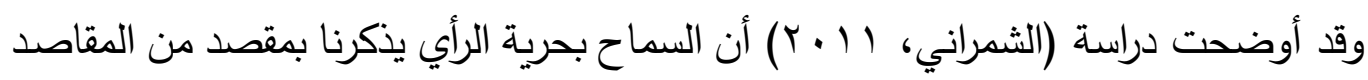

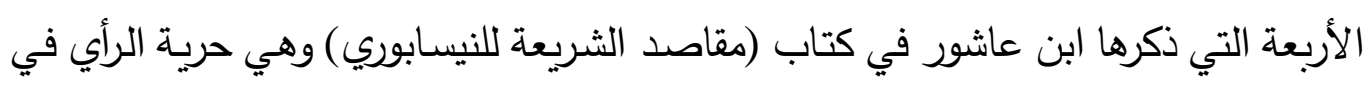

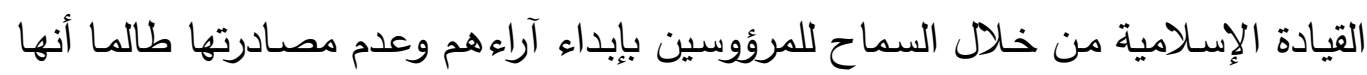
تصب في صالح الأمة وفيما تفتضيه المصالح المرسلة. القدوة الحسنة: يجب أن يكون القائد المثل الأعلى لجماعته فكرا وسلوكا وقد كان الرسول

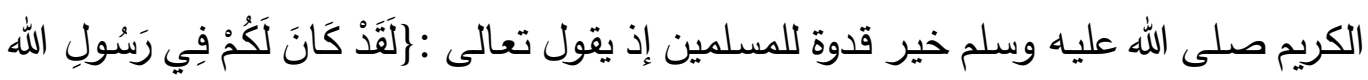

$$
\text { أُسْوَة حَسَنَةْ (سورة الأحزاب). }
$$

\الرعاية والمسؤولية: على القائد أن يكون من الجماعة (المنظمة) موقف الراعي لشؤونها

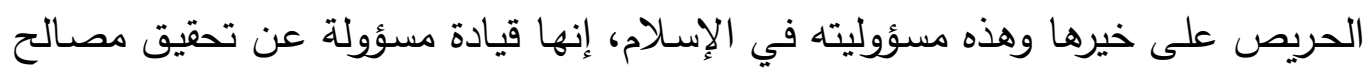
الجماعة وأفرادها والحفاظ عليها. 
ج) إسداء النصيحة: ينبغي على القائد إسداء النصيحة لجماعته وأفرادها وذلك بإشادهم لما فيه الخير وما يحقق الأهداف، ولذا يقول الرسول الكريم: "ما من عبد استرعاه الله رعية فلم يحطها بنصيحته إلا لم يجد رائحة الجنة". × الإقتاع بالحسنى: لما كانت القيادة وفق أحدث مفاهيمها تعني التأثير في تصرفات الآخرين كان على القائد إقناع جماعته بالتزام ما يراه من تصرفات محققة لأهدافها وأن يلزم جانب المحكمة فيما

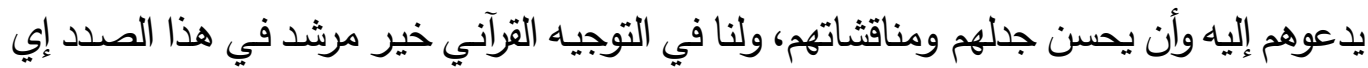

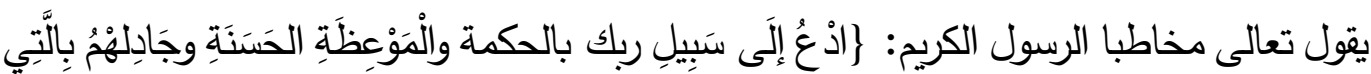

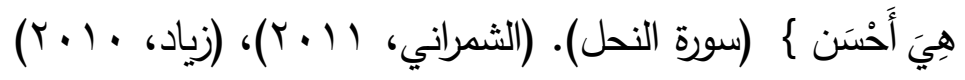

يعد عمر بن عبد العزيز من أبرز المجدين في الإسلام بعد انتهاء الخلافة الراشدة التي

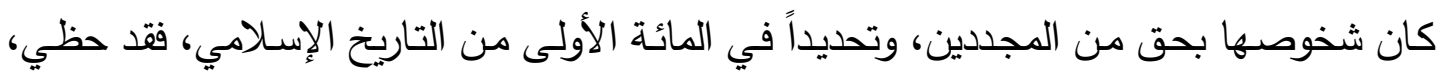

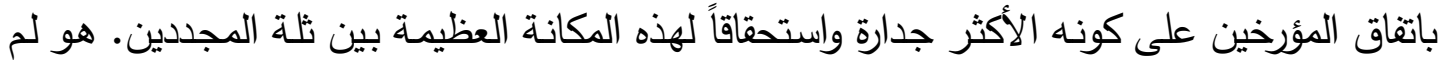

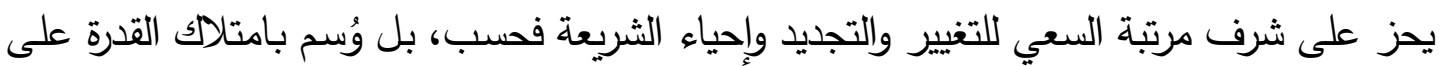

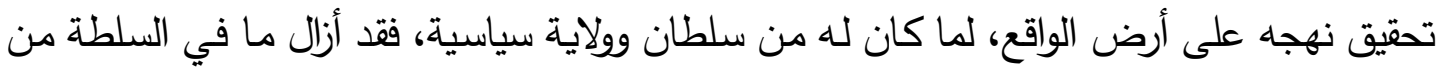

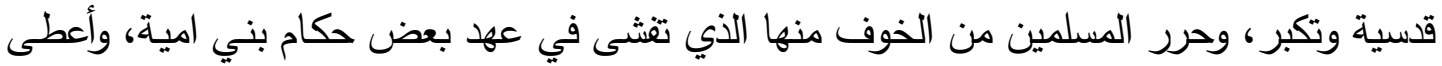

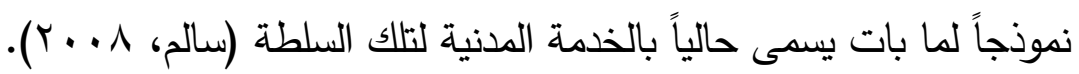

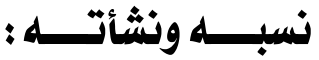

عمر بن عبد العزيز الأموي القرشي، يكنى بأبي حفص، ثامن الخلفاء الأمويين، يرجع

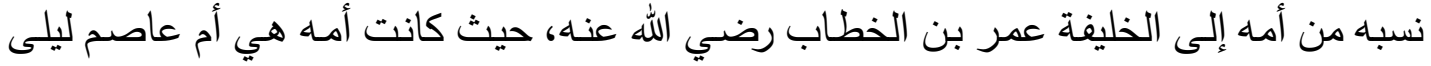

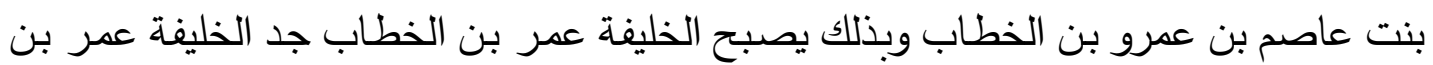

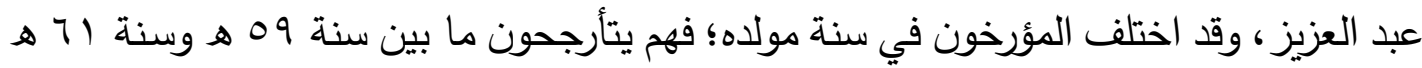

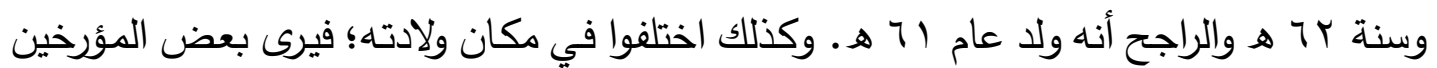

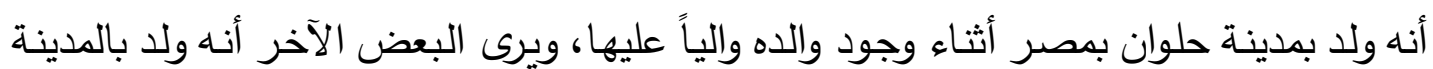

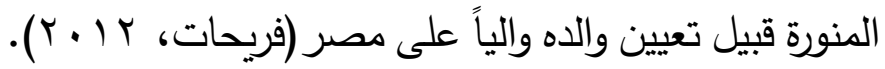
نشأ عمر بالمدينة وتخلق بأخلاق أهلها، وتأثر بعلمائها وأكب على أخذ العلم من شيوخها،

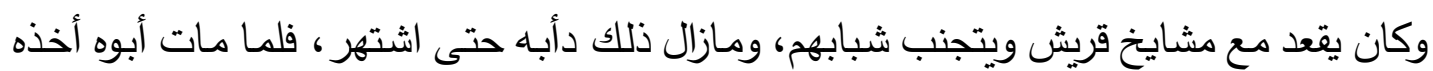

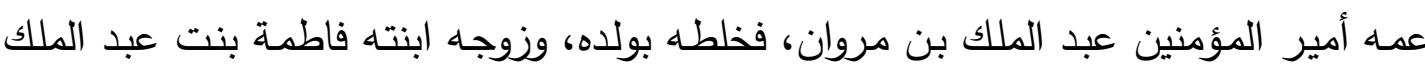

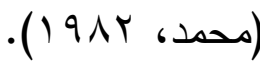




\section{خلافتــــــــ}

لقد عين واليا على المدينة وهو في الخامسة والعشرين من عمره، وفي فترة ولايته نعمت

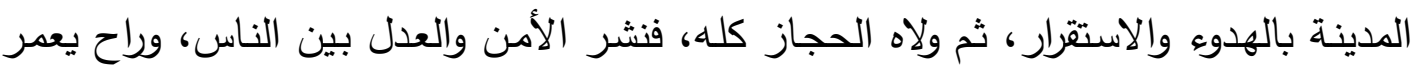
المساجد، بادئاً بالمسجد النبوي الثريف، فحفر الآبار، وشق الترع، فكانت ولايته على مدن الحجاز

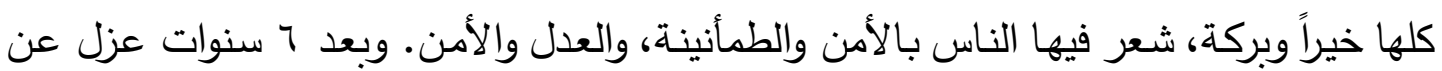
ولايته بسبب وشاية استجاب لها الوليد، وعاد إلى الثام، ولم يتول منصبا (فريحات، ب ا • r).

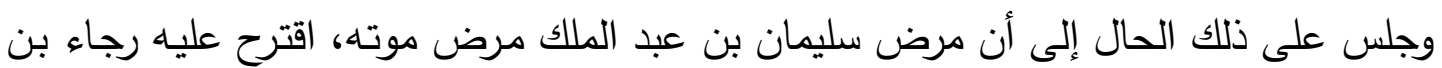

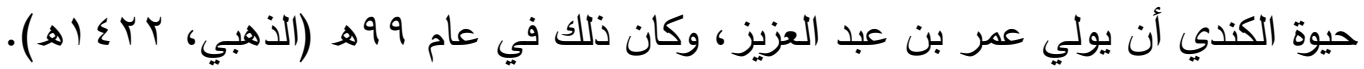

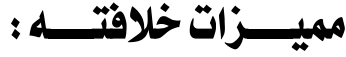

× العــــل كـان عمـر بـن عبد العزيـز يـرى أن المسؤولية تتمثل بالقيـام بحقوق النـاس،

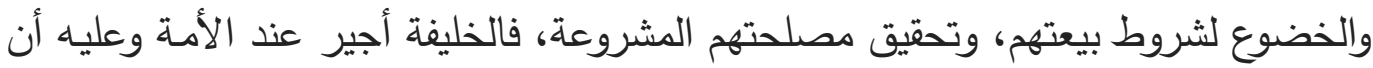

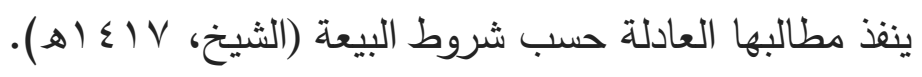

كر رد المظالم: بدأ عمر بن عبد العزيز برد المظالم بنفسه، روى ابن سعد: لما رد عمر بن

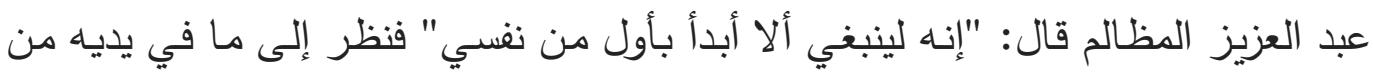

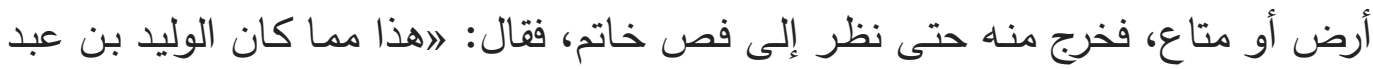

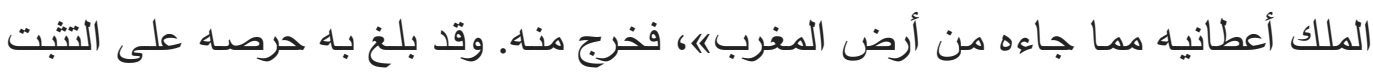

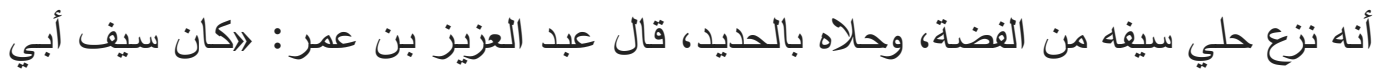

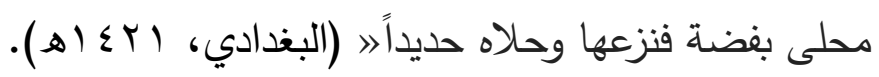

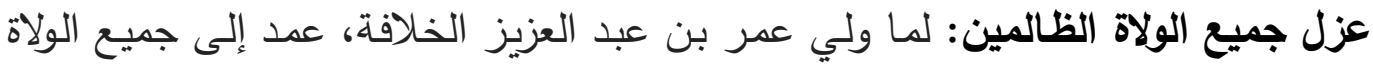

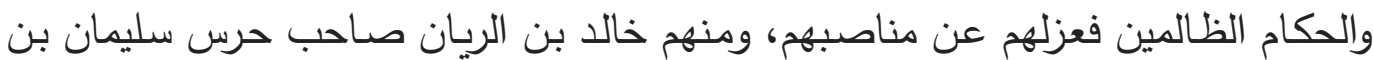
عبد الملك الذي كان يضرب كل عنق أمره سليمان بضربها، وعين محله عمرو بن مهاجر

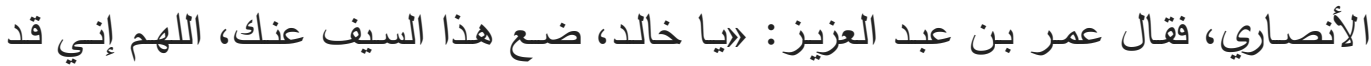

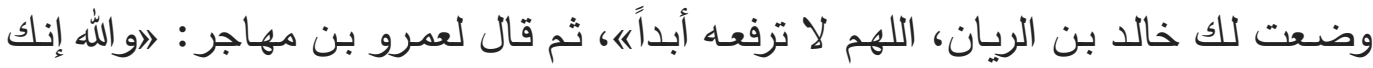
لتعلم يا عمرو إنه ما بيني وبينك قرابة إلا قربة الإسلام، ولكني سمعتك تكثر تلاوة القرآن،

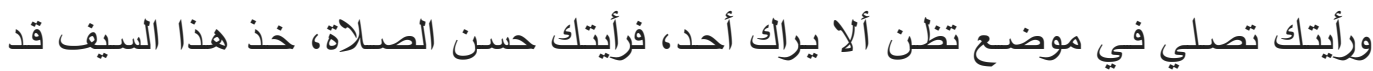

$$
\text { وليتك حرسي.» (ابن الجوزي، ع ــ (الهـ). }
$$


× العمل بالثورى: اهتم عمر بن عبد العزيز بتفعيل مبدأ الثورى في خلافته، ومن أقواله في

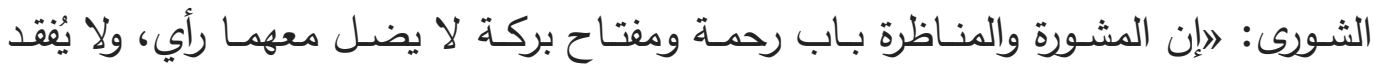

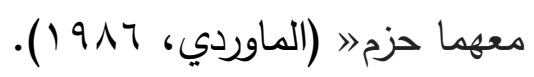

نشر العلم بين الرعية: حرص عمر على نشر العلم بين رعيته وتفقيههم في الدين وتعريفهر

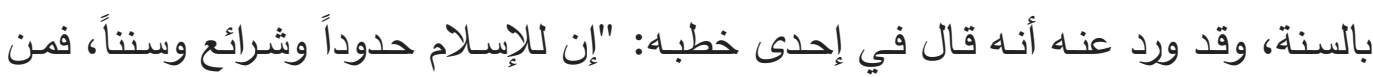

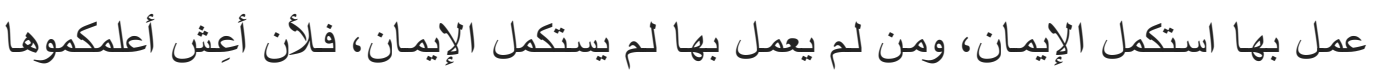

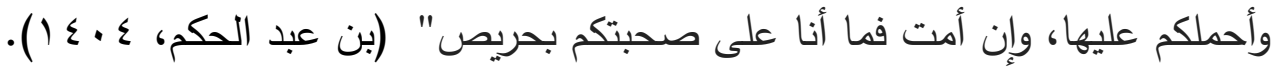
ولقد قال عنه النووي: " أجمح العلماء على جلالمة عمر وفضله، ووفور عمله، وصـلاحه، وزهده وورعه وعدله، وشفقته على المسلمين، وحسن سيرته بينهم، وبذل وسعه في الاجتهاد، وفي طاعة الله، وحرصه على اتباع آثار رسول الله صلى الله عليه وسلم، والاقتداء بسنته، وسنة الخلفاء

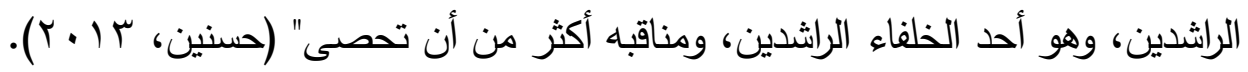

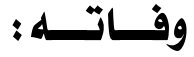

توفي عمر بن عبد العزيز سنة 1. 1 هـ ودفن في منطقة دير سمعان من أعمال معرة

النعمان بالقرب من حلب بسوريا، وقد قال بعض المؤرخين: إن عمر بن عبد العزيز قد قتل

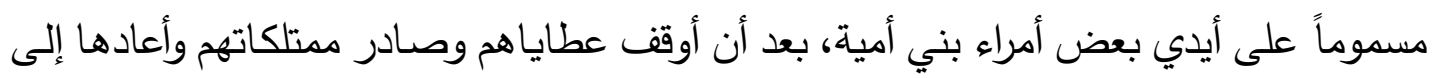
بيت مال المسلمين، وهذا الرأي هو الأرجح. لقد حضره أجله ولاقى ربه عادله بلاً في الرعية قائماً فيها

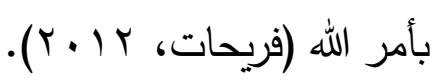

\section{منهجية الدراسة وإجراءاتها:}

\section{منهجيــة الدراســة :}

اعتمدت الدراسـة الحاليـة على المنهج الوصـفي التحليلي، القـائع على جمـع وتحليل

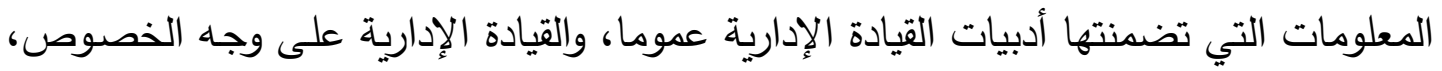

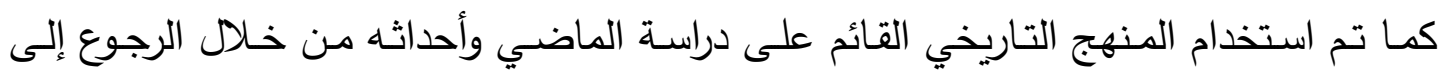

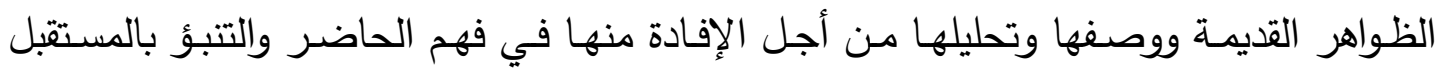

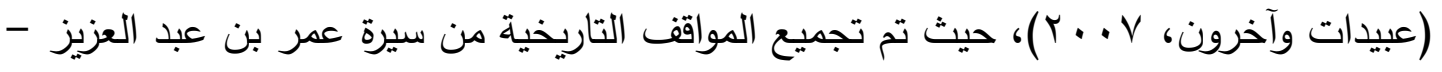
رضي الله عنه- ذات العلاقة بمشكلة البحث، ثم تحليلها ودراستها. 


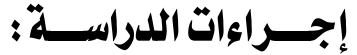

لتحقيق أهداف الدراسة، قامت الباحثة بمراجعة الأدبيات المتخصصة في مجال القيادة

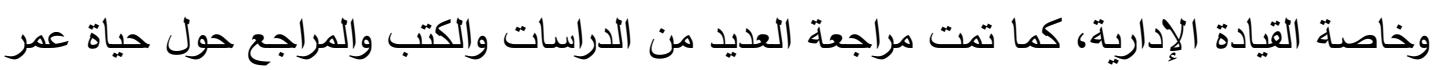
بن عبد العزيز وصفاته القيادية.

\section{تفسيـر وتدليـل النتائســة:}

من خلال الإطار النظري للدراسة الحالية، وكذلك مراجعة الدراسات السابقة؛ سيتم في هذا

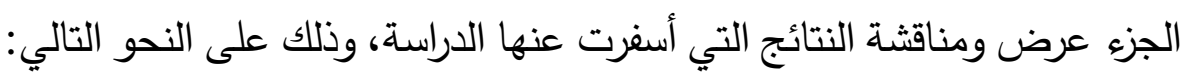

\section{إجابة السؤال الأول: ما مفهوم القيادة الإدارية في الفكر الإسلامي؟}

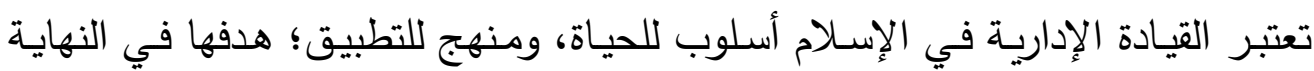

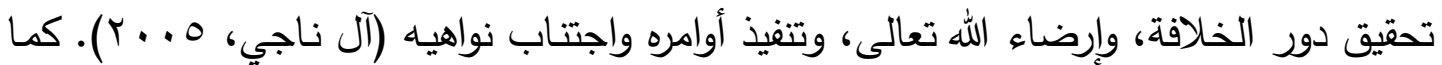
تمتاز القيادة الإدارية الإسلامية بأنها قيادة وسيطة كالإسلام الذي يحب ولفي الوسطية في كل شيء

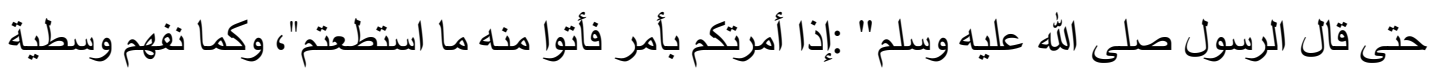

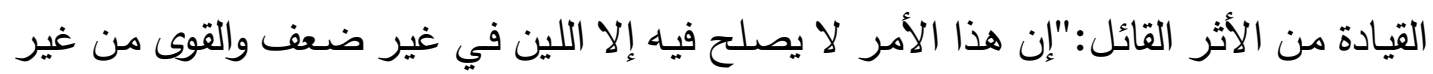

$$
\text { عنف"( الضحيان، V • ع أه). }
$$

يثير مفهوم القيادة بمعناها العام في الإسلام بأنها السلوك الذي يقوم به شاغل مركز

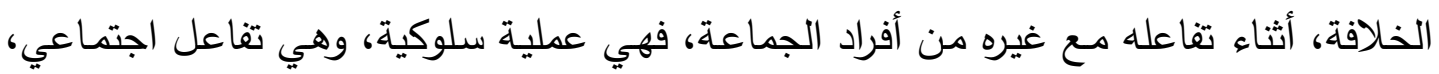

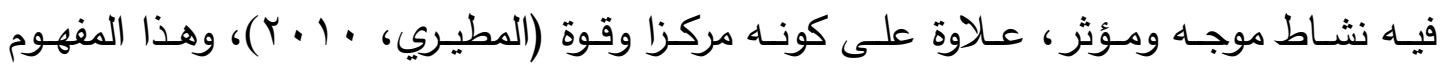

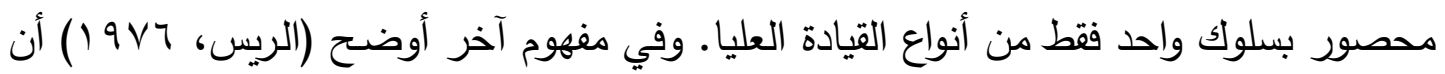

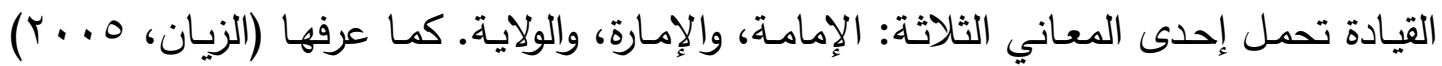

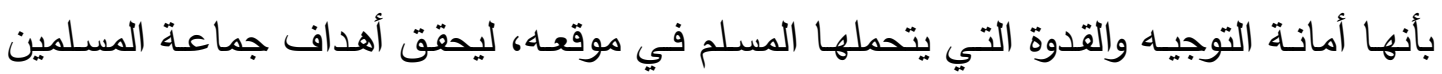

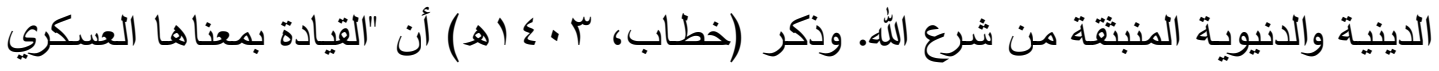

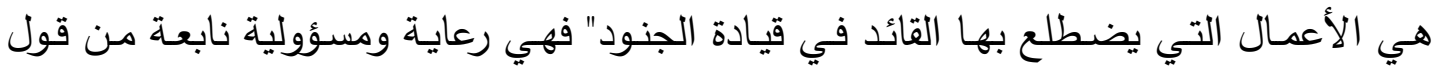
الرسول صلى الله عليه وسلم: (كلكم راع وكلكم مسؤول عن رعيته).

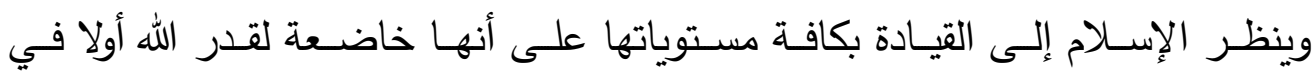

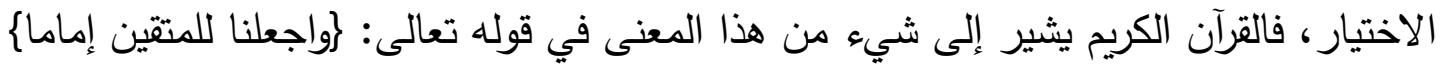

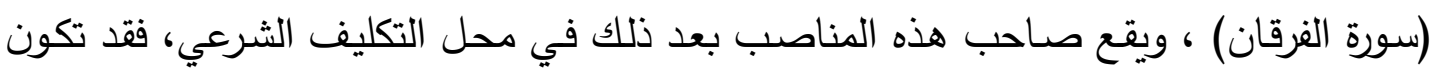


القيادة نعمة عليه تحتاج إلى شكر ، وقد تكون فتنة تحتاج إلى صبر ،؛ لذا لا تعطى القيادة لمن

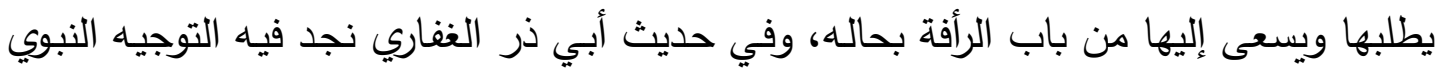

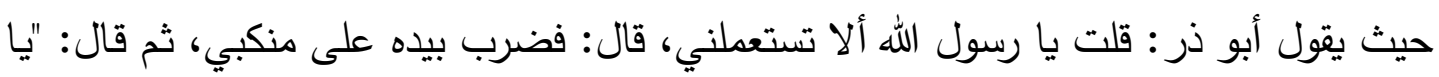

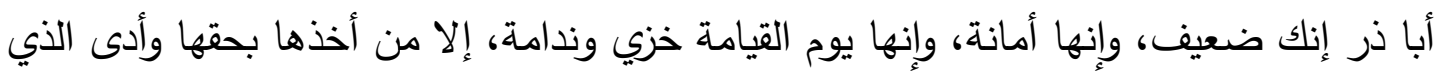

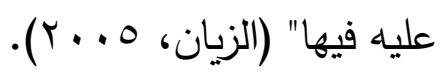

وتعتبر القيادة الإسـلامية ذات منهج رباني، وأهداف سامية؛ تسعى للمشاركة والتناصح

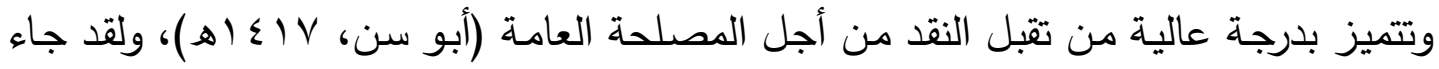

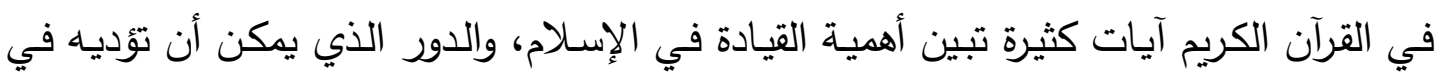

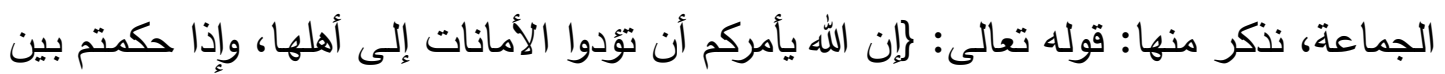

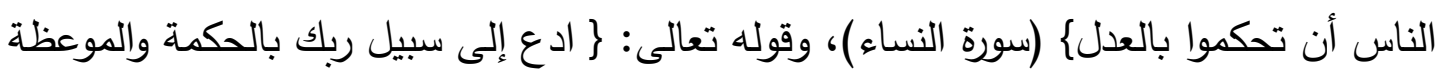
الحسنة وجادلهم بالتي هي أحسن (سورة النحل)، وقوله تعالى: (ياليا أيها الذين آمنوا أطيعوا الله وأطيعوا الرسول وأولي الأمر منكم) (سورة النساء). ويتضح من الآيات السابقة أهمية القيادة في

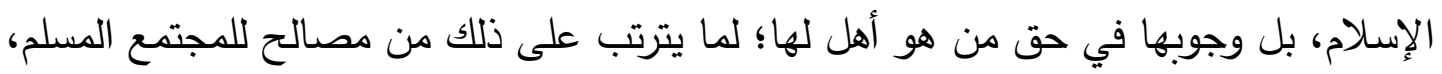

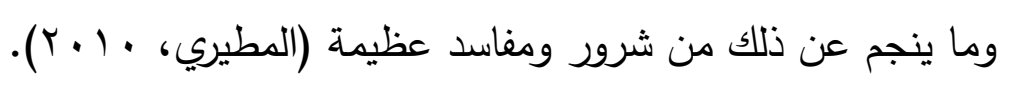

\section{إجابة السؤال الثاني : ما الصفات القيادية التي اتسر بها عمر بن عبد العزيز؟؟}

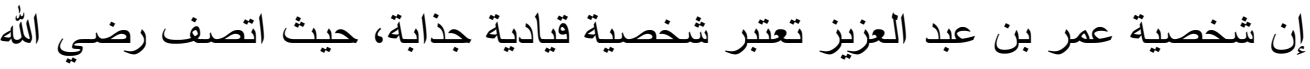

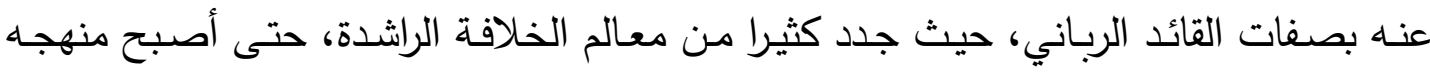

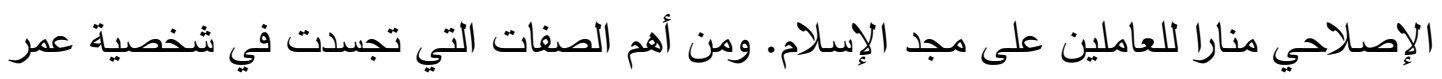

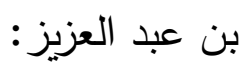

1- شدة خوفه مـن الله تعالى: كان عمر بن عبد العزيز شديد الخوف من الله تعالى، تقول

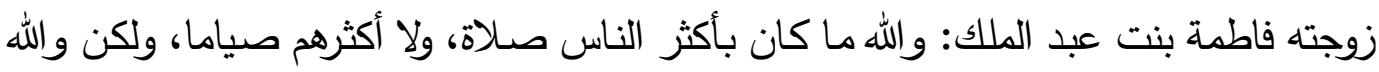
ما رأيت أحدا أخوف من الله من عمر، لقد كان يذكر الله في فراشه، فينتض انتض انتفاضة العصفور

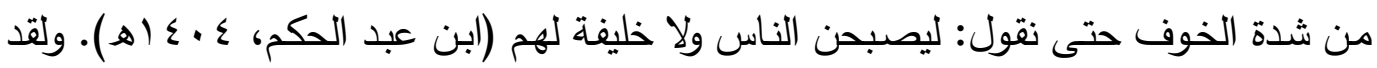

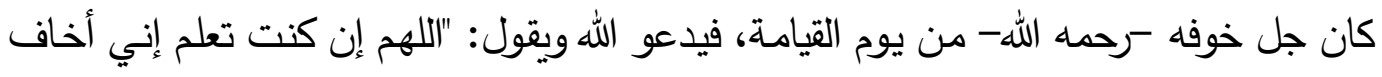

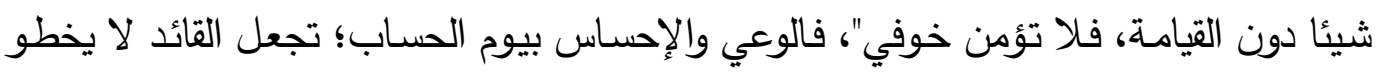

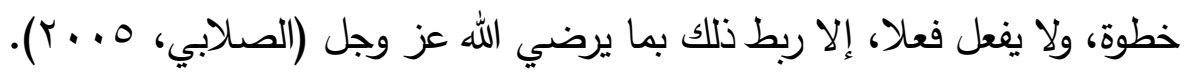


ץ-1العلــــم: لقد اتفقت كلمة المترجمين له على أنه أحد أئعـة زمانه المليء بأئمة التابعين، فقد أطلق عليه كلُ من الإمامين: مالك، وسفيان بن عيينه، وقال فيه مجاهد - وحسبك به: "أتيناه

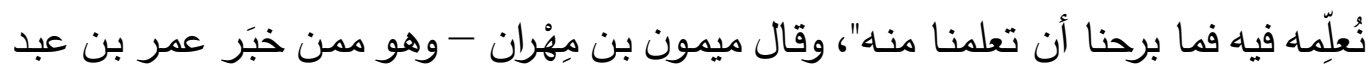

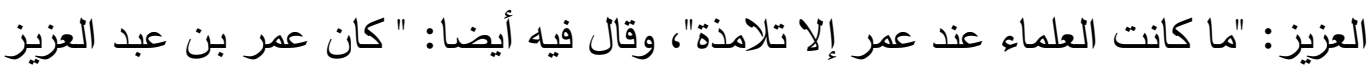

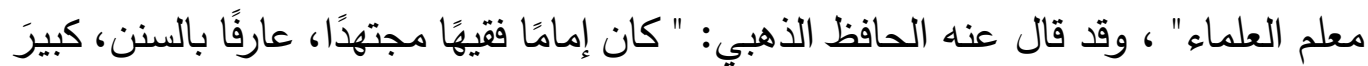

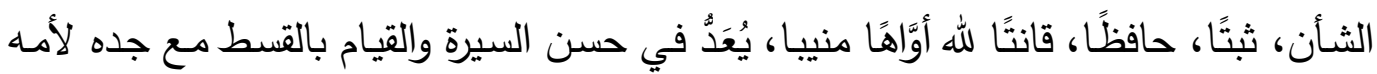
عمر، وفي الزهد مع الحسن البصري، وفي العلم مع الزهري، ولكن موته قرُب من موت فئه

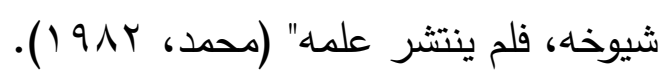
ب-الزهـ والورع: كان شديد المحاسبة لنفسو ورِرًِا تقيًا، كان يقسم تفاحًا أفاءه الله على

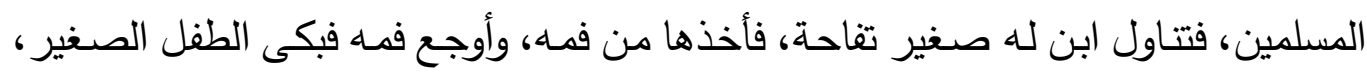

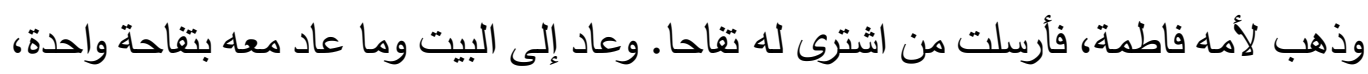

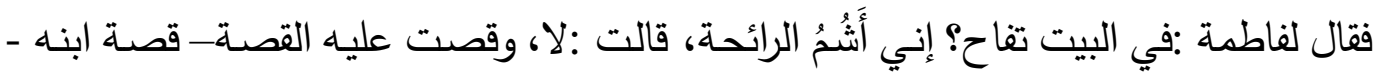

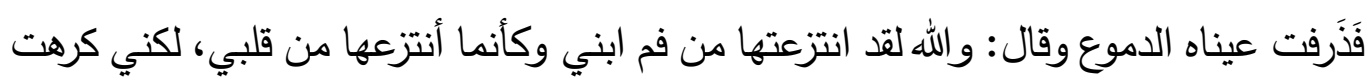

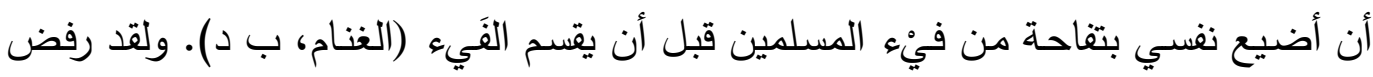

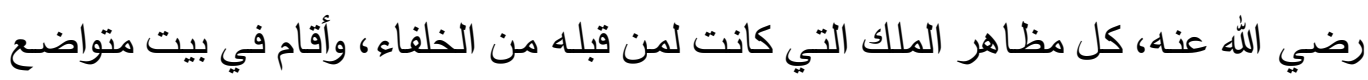

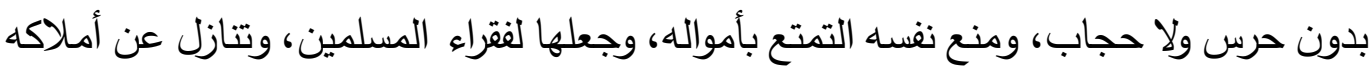

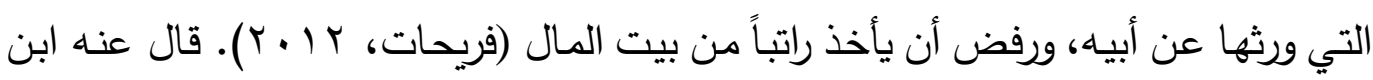
كثير : " فكان يلبس القميص الغليظ المرقوع ولا يغسله حتى يتسخ جدا، وكان يلبس الفروة الغليظة، وكان سراجه على ثلاث قصبات في رأسهن طين، ولم يبن شيئا في أيام خلافته،

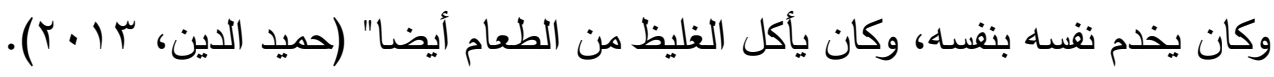

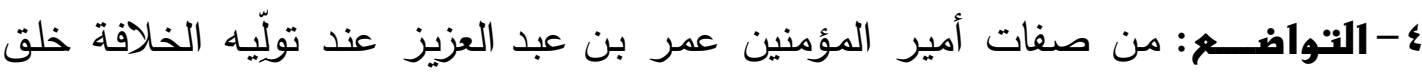
التواضع، ولا شك أن التواضع صفة حميدة، تحبب المرو الذي يتخلق بها إلى الناس، وتعظمهـ

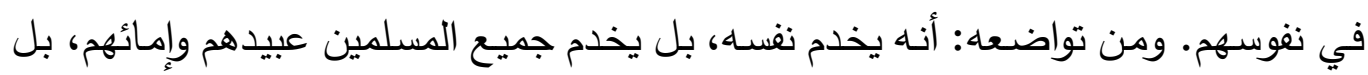

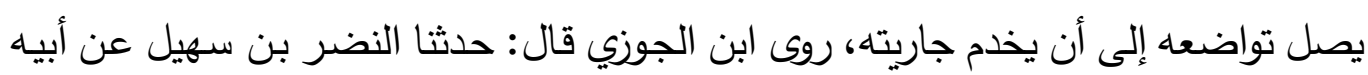

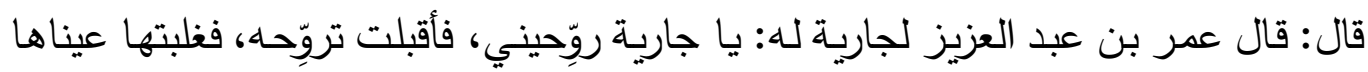

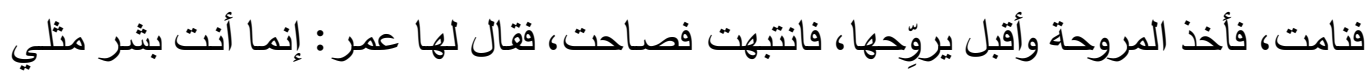


أصابك من الحرِّ ما أصابني، وأحبيت أن أروحك مثل الذي روَّحتني. كما كان ينهى حراسه

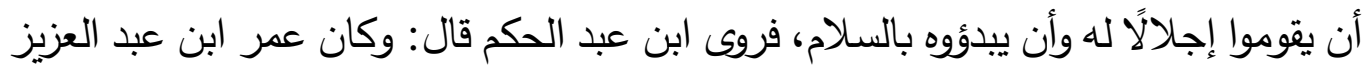

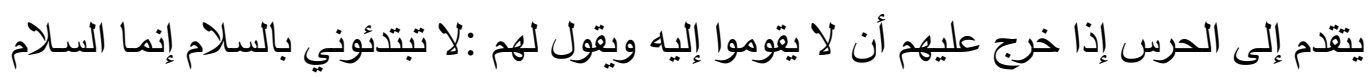

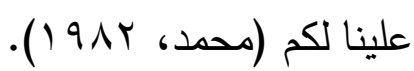
ه - الصفح والعفو: ومن الصفات التي تجست في شخصية عمر بن عبد العزيز، الحلم والصفح،

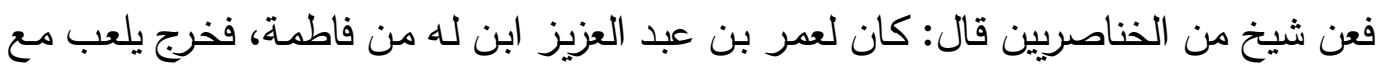

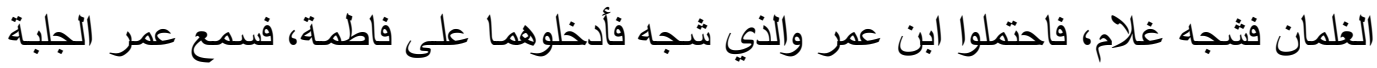

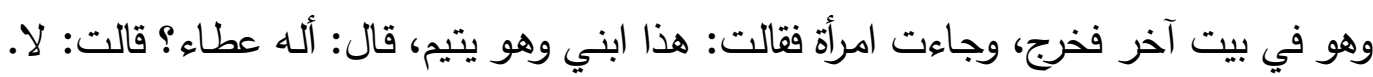

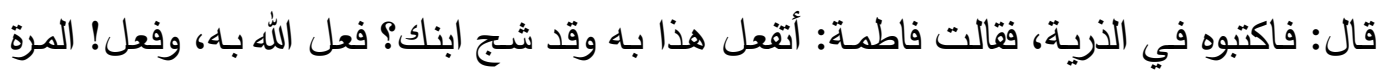



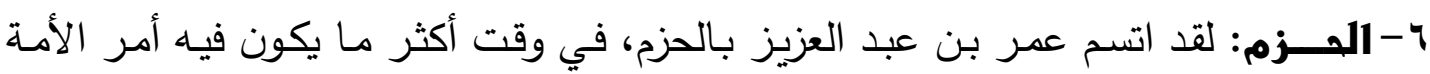

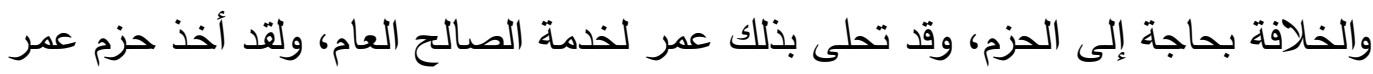

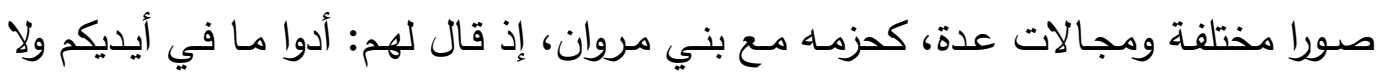
تلجؤوني إلى ما أكره، فأحملكم على ما تكرهون، فلم يجبه أحد منهم، فقال: أجييوني، فقال فئال

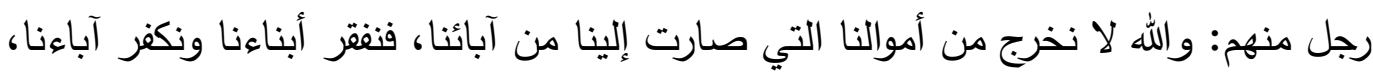

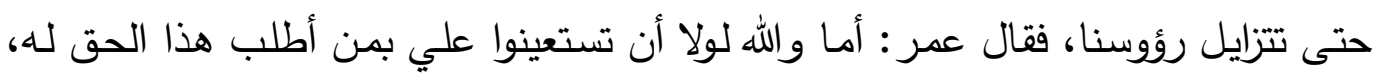

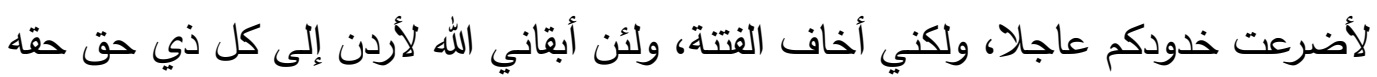

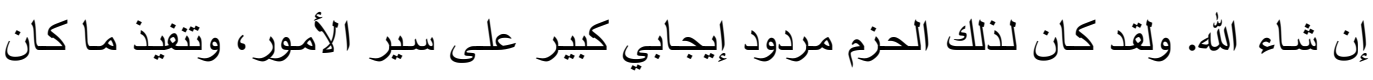

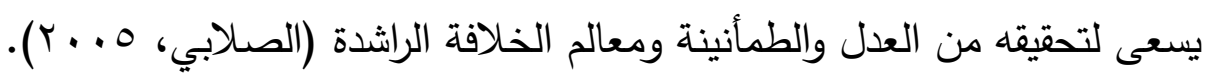

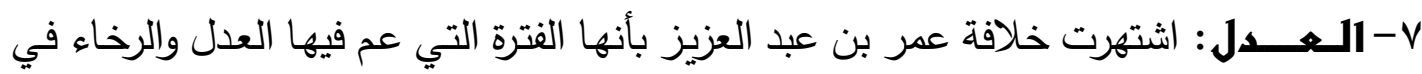

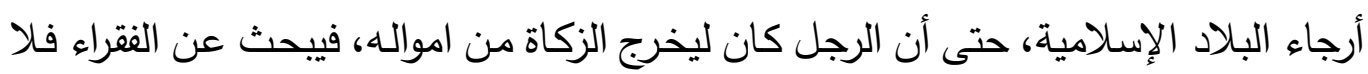

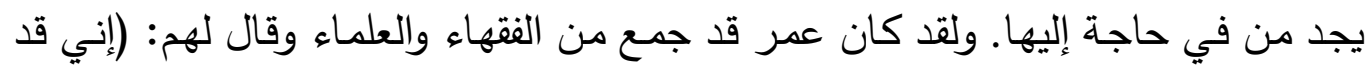

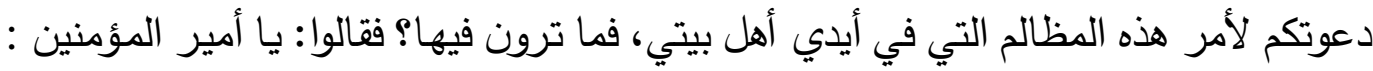

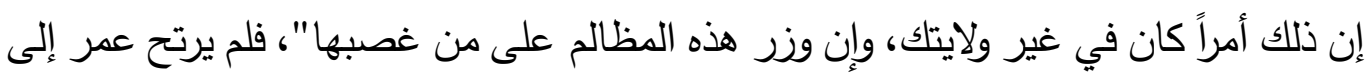

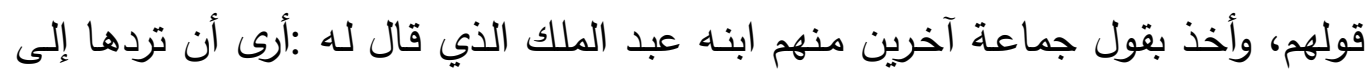

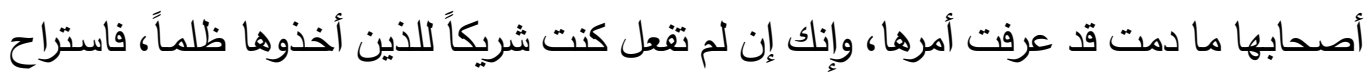


عمر لهذا الرأي وقام يرد المظالم إلى أهلها. كان عمر بن عبد العزيز لا يحكم على أحد

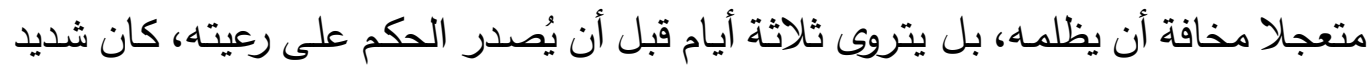

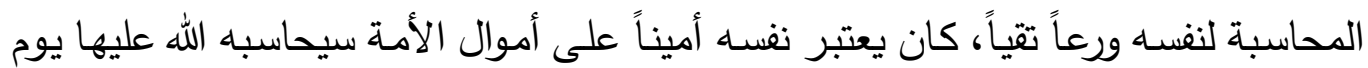

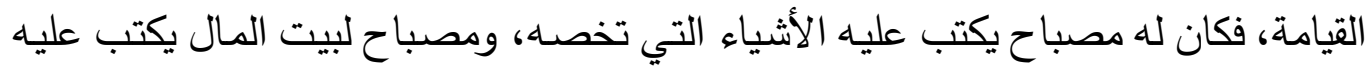

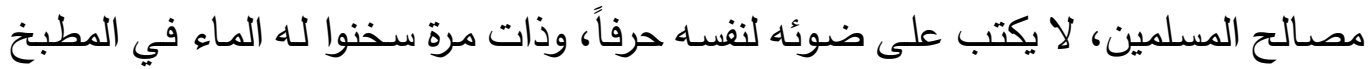

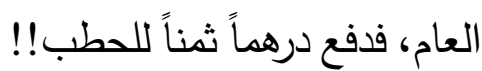
لقد كان همه الأول والأخير أن يعيش المسلمون في عزة وكرامة، ينعمون بالخير والأمن

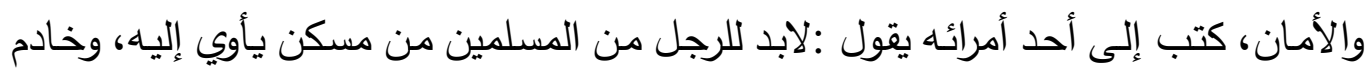

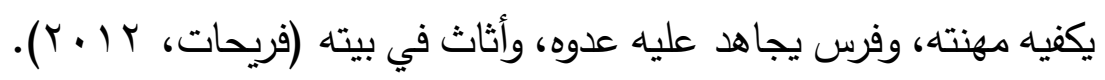

^-1النزامه بالشورى: أظهرت ولاية عمر بن عبد العزيز للمدينة أنه يدير ولايته بالثورى، فقد كون مدة ولايته مجلسًا للشورى من عشرة فقهاء وكان لا يقطع أمرًا بدونهم (عبد العزيز ،

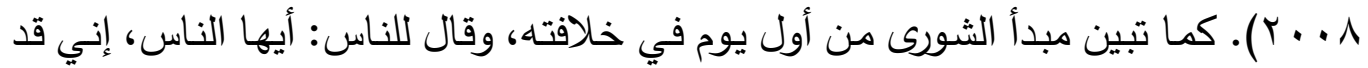

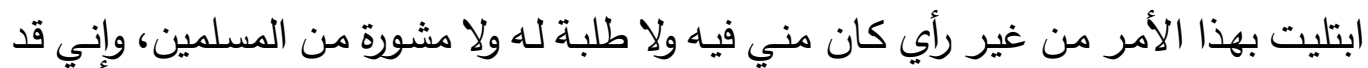

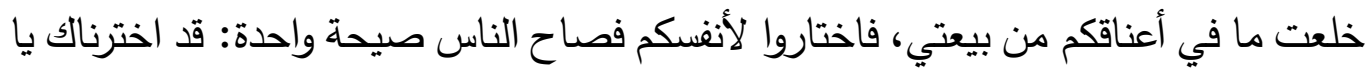

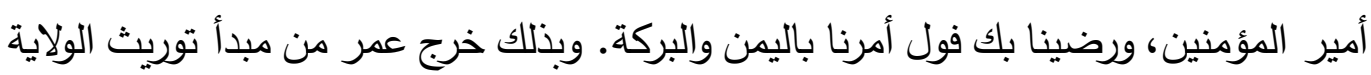

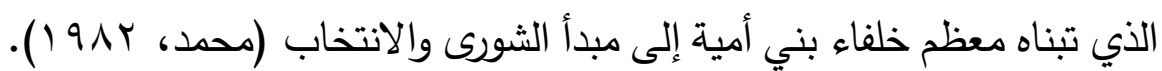

ولقد أوضحت دراسـة (القحطاني، لو99 ( ) أن نجاح عمر في قيادته، وحسن إدارته،

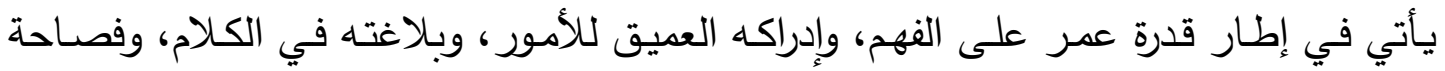

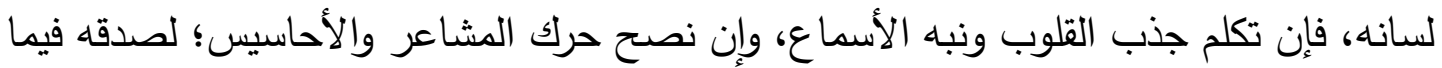
يقول، ولأن ما يقوله يخرج من قلبه، فهو الذي يقول: " لا ينفع القلب إلا ما خرج من القلب"،

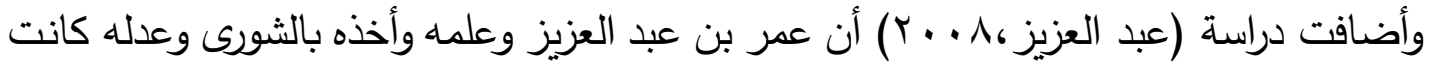
كلها تتبئ (حينما ولي أمر المسلمين) بأنه سيقود الدولة الإسلامية قيادة ناجحة.

\section{إجابة السؤال الثالث : ما منهج عمر القيادي في إداراته لللولة:}

لا تزال خلافة عمر بن عبد العزيز حجة تاريخية، على كل أولئك الذين يشككون في

إمكانية إقامة نظام إداري إسلامي، وبرهاناً ساطعاً على أن الاحتكام للشريعة الربانية هو وحده الذي يكفل للناس السعادة في الدنيا والآخرة (نورستاني، ؛ (. ب). ولقد كان لعمر بن عبد العزيز 


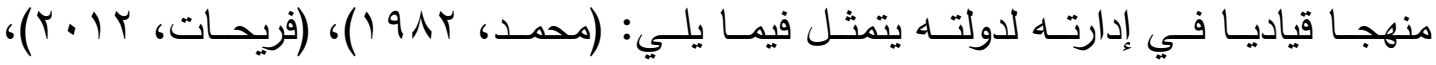

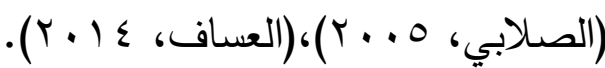

1- هسن افتيـار الأعوان: كان من أول قرارات عمر بن عبد العزيز عزل ولاة الجور الذين

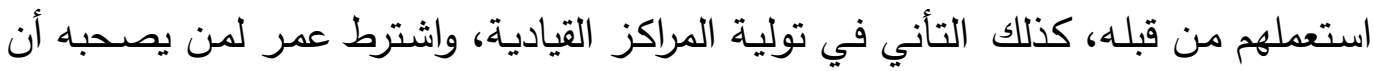
يوصل إليه حاجات الناس، ويدله على العدل، ويعينه على الحق، ويؤدي الأمانة. وكان

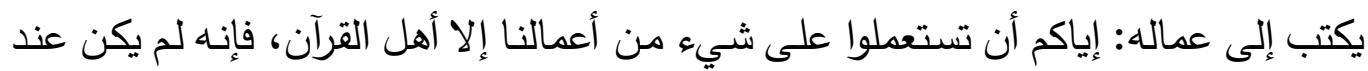

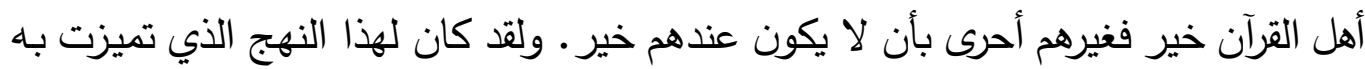

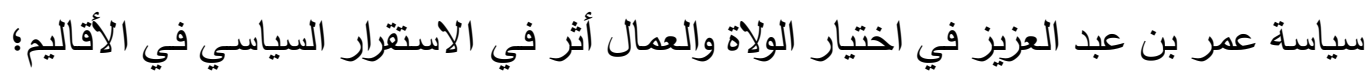
حيث رضي الناس سير عماله وحمدوا فعالهم. r-1الإشراف المباشر على شؤون الدولة: أشرف عمر بن عبد العزيز بنفسه على ما يتم في دولته من أعمال صغرت أو كبرت، وكان يتابع عماله في أقاليمهم وساعده على ذلك الك أجهزة الدولة التي طورها عبد الملك بن مروان، كالبريد، وجهاز الاستخبارات الكبير الممتد في

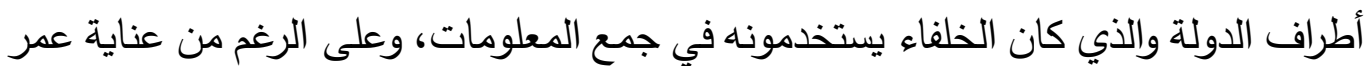

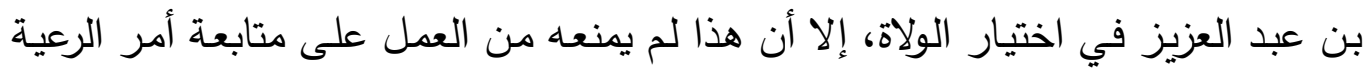

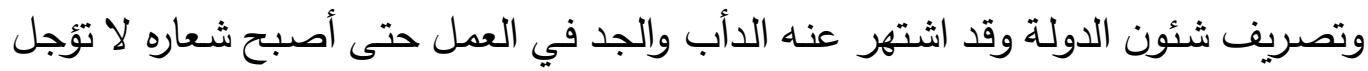

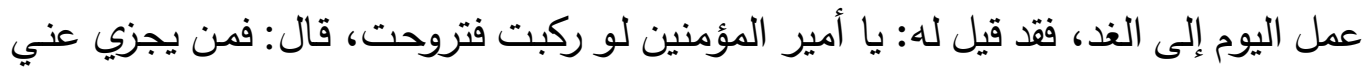

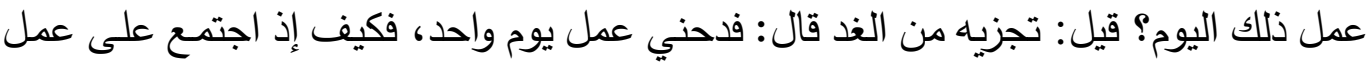

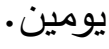
r-1التخطيط: وعمر بن عبد العزيز لم يكن ليتخذ قرارًا دونما تخطيط، وتوخ لعواقب الأمور ،

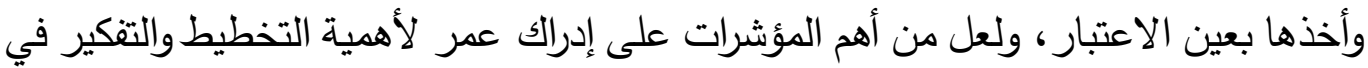

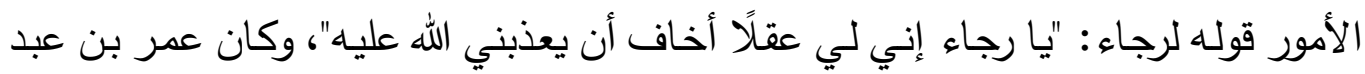
العزيز يعتمد على الله ثم جمع المعلومات والقدرة على حسن قرأتها، واستشراف المستقبل وتحقيق الأهداف المطلوبة، ففي ذلك يقول عمر : من عمل على غير علم كان يفسد أكثر مما

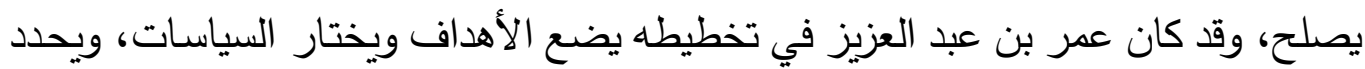

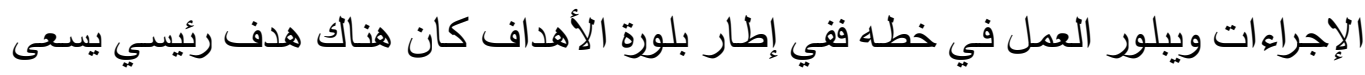
عمر لتحقيقه ألاوهو الإصلاح والتجديد الراشدي على منهاج النبوة والخلافة الراشدة. 
ع- التنظيم: فمن حيث التتظيم الهيكلي للعمل، نجد عمر بن عبد العزيز قد جزأ أعمال الدولة

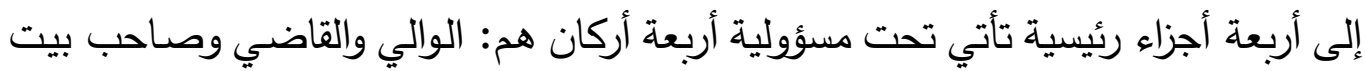

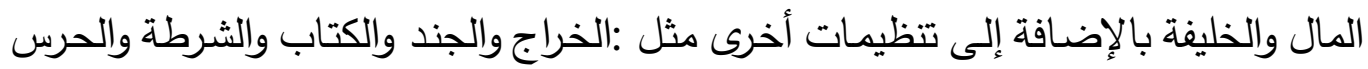

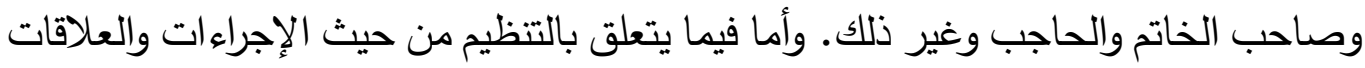

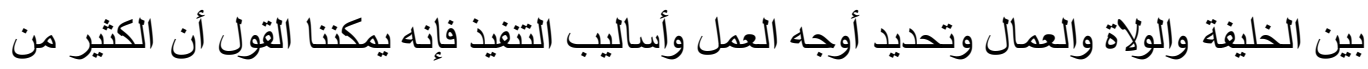
كتب عمر لعماله تسعى لتحقيق هذا الغرض وإيضاح هذا الجانب التنظيمي من العملية

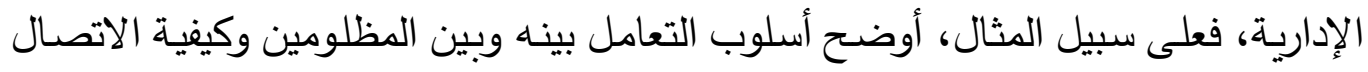

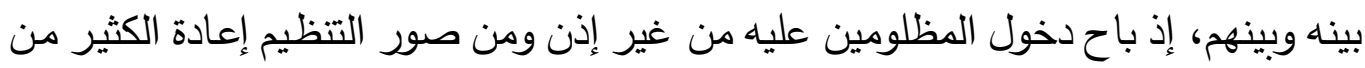

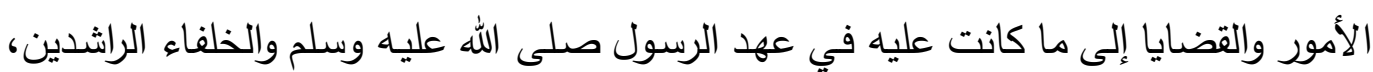
ومثال ذلك أمره بإرجاع مزرعته في خيبر إلى ما كانت عليه في عهد رسول فيل اللها ه- الوقاية مز الفساد الإداريي: سعى عمر بن عبد العزيز لتحقيق السلامة من الفساد الإداري،

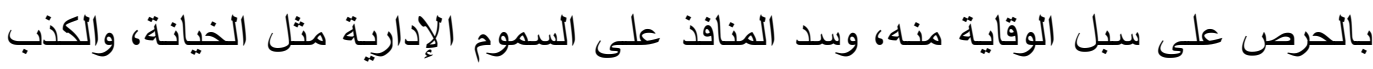
والرشوة والهادايا للمسؤولين والأمراء والإنسراف وممارسة الولاة والأمراء للتجارة واحتجاب الولاة الأهاء

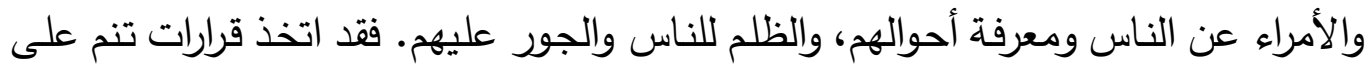

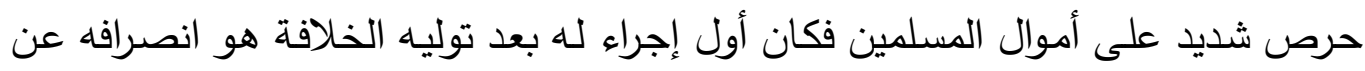
مظاهر الخلافة، إذ قربت إليه المراكب، فقال ما هذه؟ فقالوا: مراكب لم تركب قط، يركبها

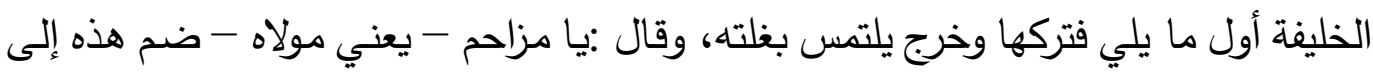

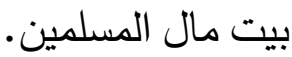

ب- المرونــــة : مارس عمر بن عبد العزيز المرونة في التفاهم والحوار والفكر وتتفيذ الأوامر والتقيد بها ومن تلك الثواهد، ما روى ميمون بن مهان، أن عبد الملك بن عمر بن عبد الثد العزئ العزيز

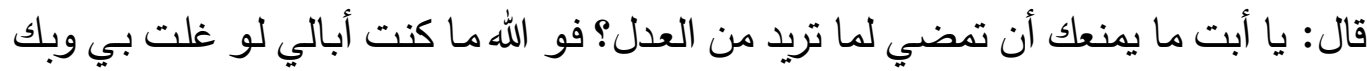

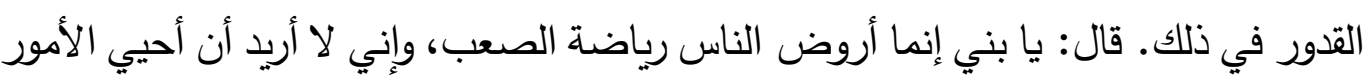

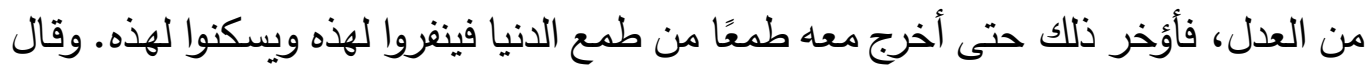

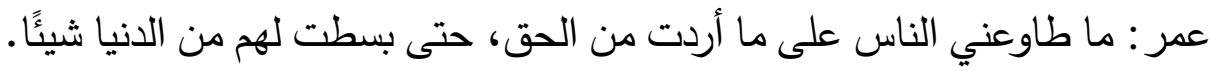

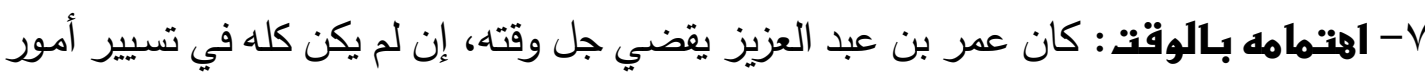

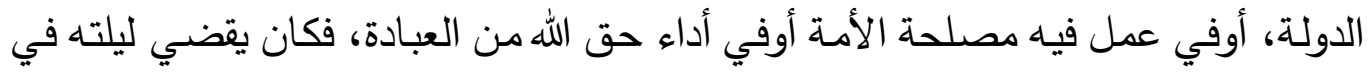


الصلاة والمناجاة وكان لا يكلم أحدًا بعد أن يوتر ـ وفي إطار اغتتام الوقت نسب إلى عمر

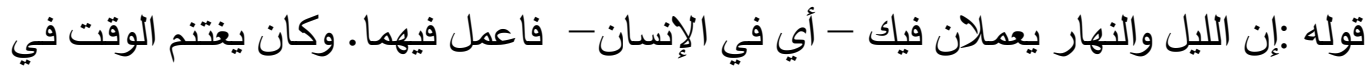
الأعمال الصالحة وفي سرعة التوجيه والبت السريع في الأمور واتخاذ القرارات الإدارية، وتلافي كل من شأنه تأخير أو عمل أو مصلحة. ^- رفز مستوى الشعب: إذا فاض المال زاد من عطاء رعيته بلا منة لأنه مالهم، ولقد جاءوه

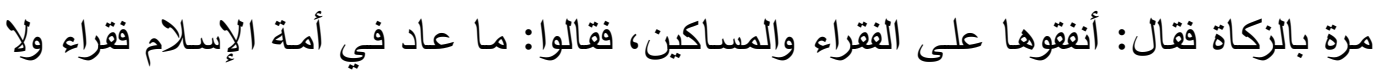
مساكين، قال: فجهزوا بها الجيوش، قالوا: جيش الإسلام يجوب الدنيا، قال: فزوجوا بها الثباب، فقالوا: من كان يريد الزواج زوج، وبقي مال، فقال: اقضوا الديون عن المدينين،

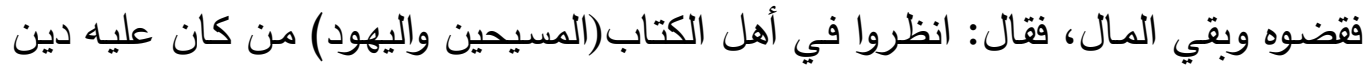

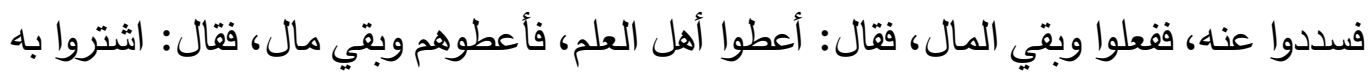
حباً وانثروه على رؤوس الجبال، لتأكل الطير من خير المسلمين.

لقد كان همه الأول والأخير أن يعيش المسلمون في عزة وكرامة، ينعمون بالخير والأمن

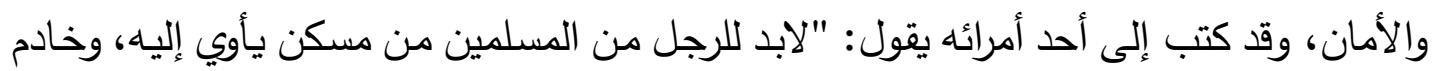

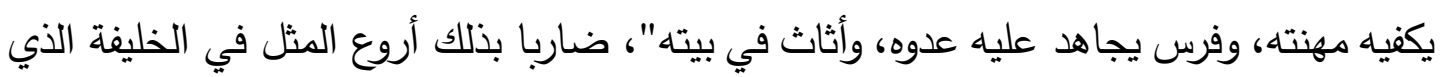

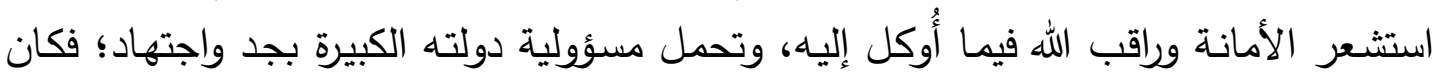

$$
\text { فامتلأت الأرض عدلا وأمنا وسماحة. }
$$

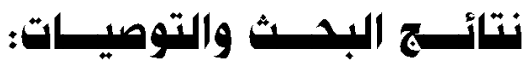

\section{تتمثل نتائج البحث في النقاط التالية:}

1- يشير مفهوم القيادة في الفكر الإسلامي إلى مجموعة الأعمال التي يقوم بهاليها القائد المسلم؛

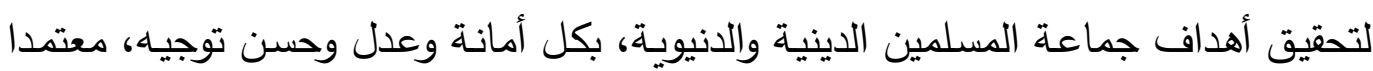
في ذلك على شرع الله وسنة نبيه.

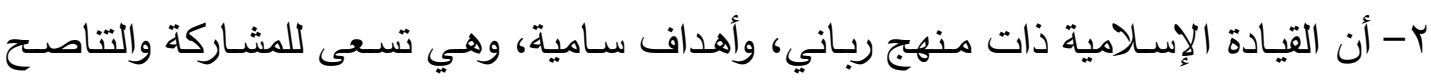

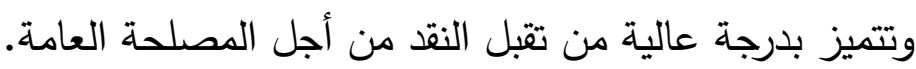

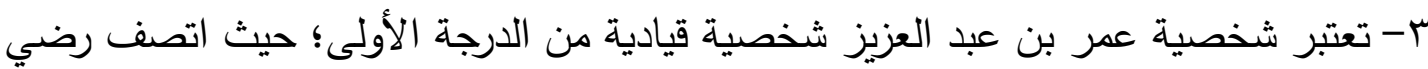

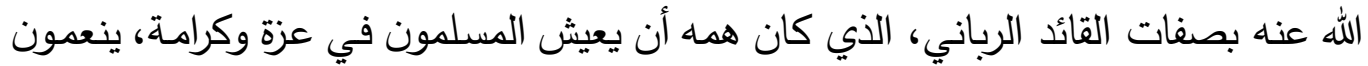

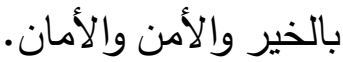




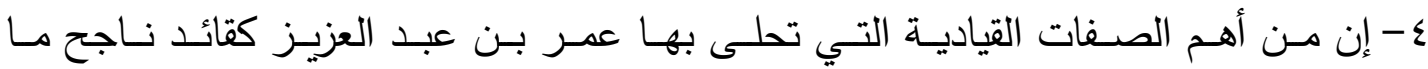

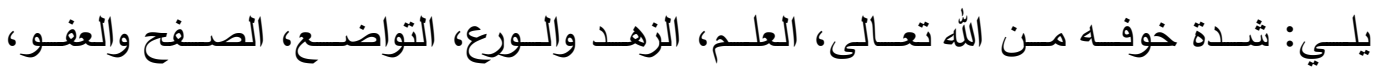
الحزم، العدل، والتزامه بالشورى.

ه- انتهج عمر بن عبد العزيز منهج التخطيط والتنظيم في إدارته للدولة؛ فعرفت فترة خلافته التهاء

$$
\text { بأنها الفترة التي عم فيها العدل والرخاء أرجاء البلاد. }
$$

1- لقد انتهج عمر بن عبد العزيز منهج قيادي واضح المعالم؛ تجلت فيه سياسته الحكيمة،

$$
\text { وعدله الناصع؛ ليصبح منهجه في القيادة مثالا يحتذى به. }
$$

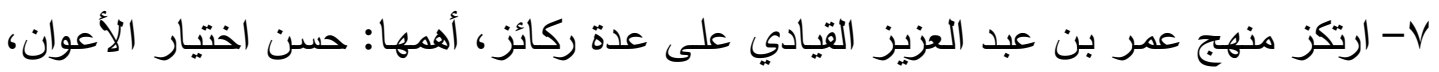

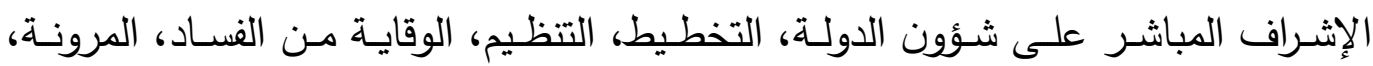

$$
\text { واهتمامه بالثعب ورفع مستوى معيشته. }
$$

1- تمثل المرحلة التي قضاها عمر بن عبد العزيز في الحكم فترة حضارية هامة في المجتمع فيته الإسلامي، حيث تم فيها التطبيق العملي للمنهج الإسلامي في القيادة تطبيقا عمليا.

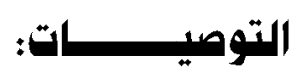

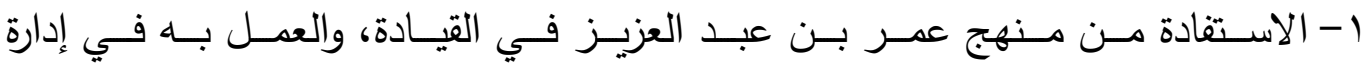

$$
\text { المؤسسات التربوية. }
$$

ب-تبنـي مــهج عمـر بـن عبــ العزيـز الإداري في عمـل دورات تطويريـة للقـادة فـي

$$
\text { المؤسسات التربوية. }
$$

ب- الاهتمـام بنشــر الــوعي الكـافي بأهميــة تحلــي القيــادات بالصــفات الإســلامية

$$
\text { المطلوبة شرعا في القيادة. }
$$

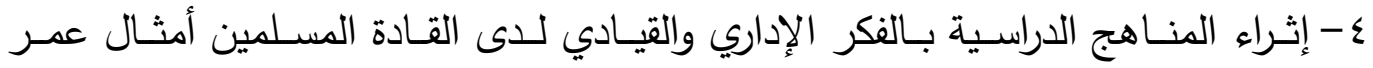

$$
\text { بن عبد العزيز. }
$$

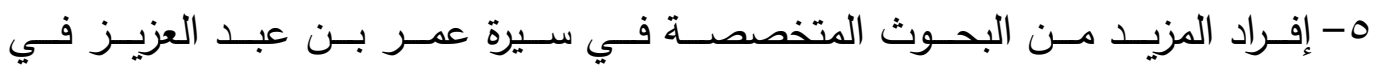

$$
\text { الجوانب الإدارية والتنظيمية. }
$$

1- عهـل دراسـات أخـرى عـن شخصـيات قياديـة إسـلامية، وكيفيـة الاسـتفادة منهـا في

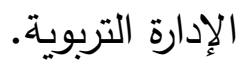




\section{2}

ابن الجوزي، عبد الرحمن. (ع • أهـ). سيرة ومناقب عمر بن عبد العزيز الخليفة الزاهد. دار

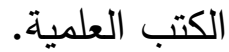

أبو سن، أحمد. (V ( إ (هـ). الإدارة في الإسلام. ط r. الرياض. دار الخريجي للنشر والتوزيع.

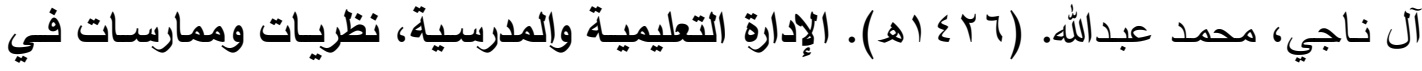

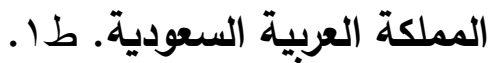

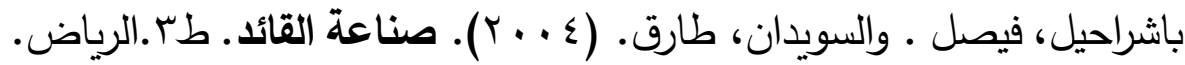

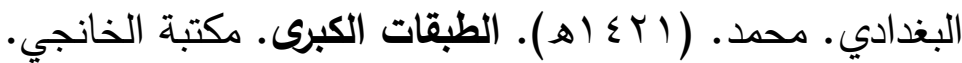

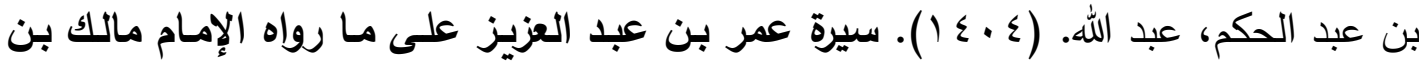

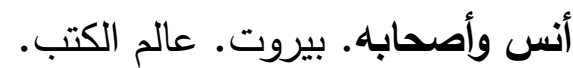

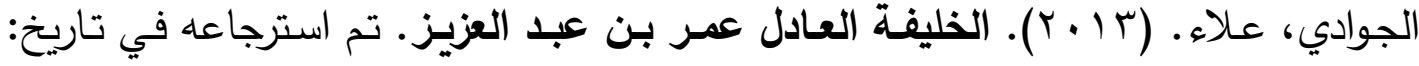

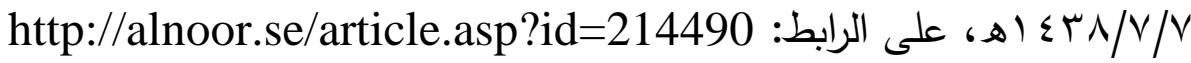

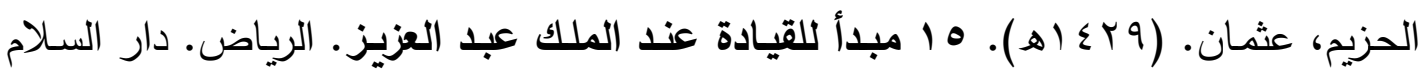

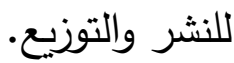
حسنين، أحمد. (T ا • ץ). مواعظ عمر بن عبد العزيز: مصلح دولة الخلافة. تم استرجاعه

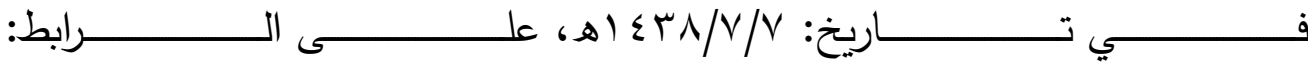
http://t.essirage.net/arc/index.php/2013-06-16-10-13-41/28472013-09-01-19-04-43.html

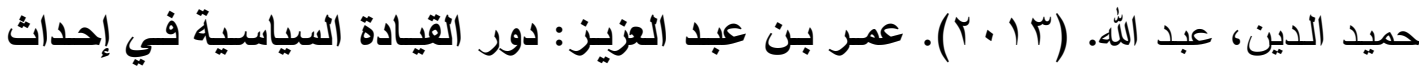

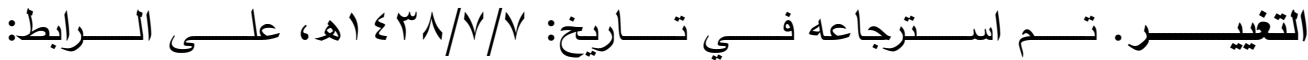
http://amiymh.blogspot.com/2013/01/blog-post_7.html خطاب، محمود. (r • ـ اهـ). بين العقيدة والقيادة. دار القلم. دمشق.

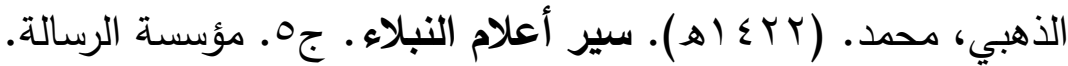

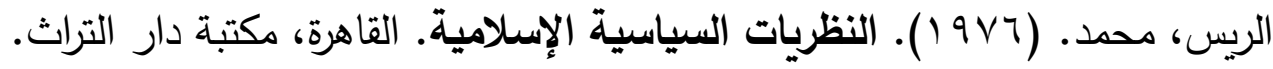

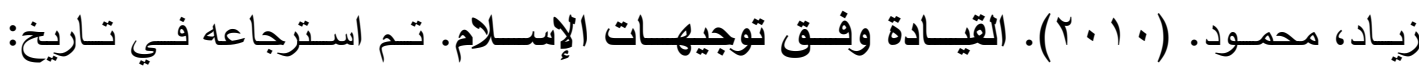

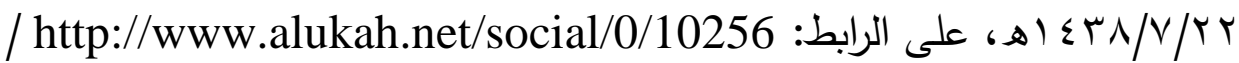

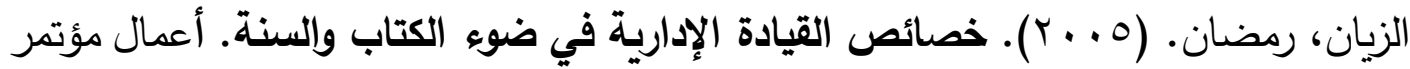
الإمام الشهيد أحمد ياسين، كلية الآداب، الجامعة الإسلامية بغزة. فلسطين.

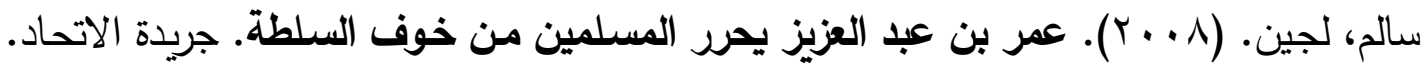

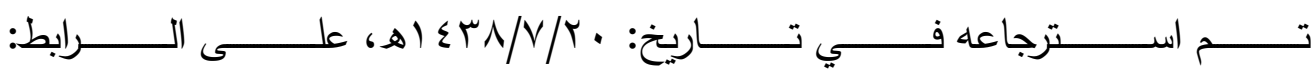
http://www.alittihad.ae/details.php?id=36687\&y=2008\&article=full 199 
سعادة، مريم، ونور الدين، كمال الدين، وعبدالصمد، الثيخ. (ع ا ـ ب). إصـلاحات عمر بن عبد العزيز الاقتصادية في مواجهة الفقر . المجلة الدولية للبحوث الإسـلامية والإنسانية

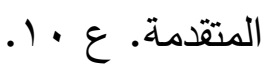

شلبي، محمود. (9 • ( اهـ). حياة عمر بن عبد العزيز. بيروت، دار الجيل للنشر .

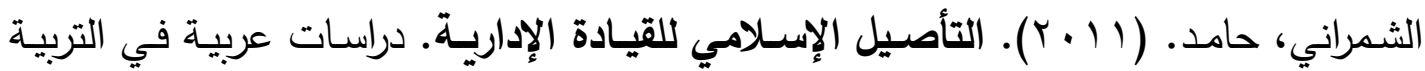

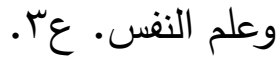

شهاب، شهرزاد. ( • ( • (ب). القيادة الإدارية ودورها في تأصير روابط العلاقات العامـة. مجلة

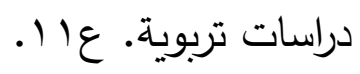

الشيخ، عبد الستار • (v) أهـ). عمر بن عبد العزيز خامس الخلفاء الراشدين. دمشق. دار القلم.

الصـلايلي، علي. (0 ץ). أمير المؤمنين عمر بن عبد العزيز : معالم التجديد والإصـلاح

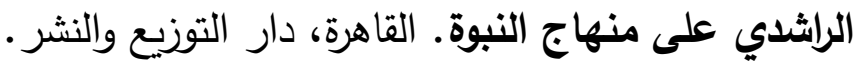
الضحيان، عبد الرحمن. (v · ع اهـ). الإدارة في الإسلام الفكر والتطبيق. دار دار الشروق.

طاهر ، علوي. (T . . ץ). القيادة التربوية في الإسلام. مجلة كلية التربية. ع^. اليمن.

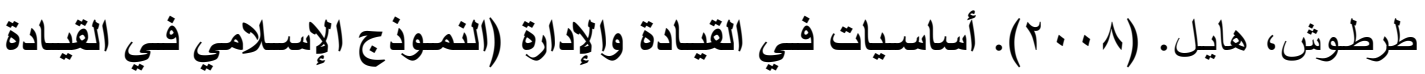

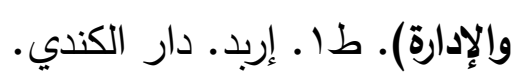

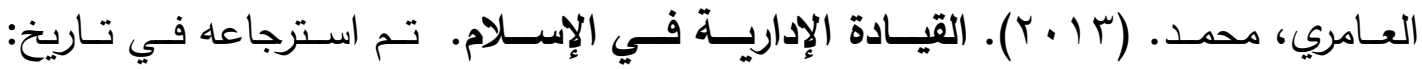

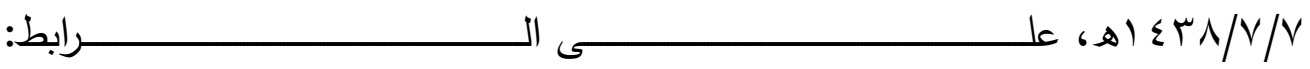
http://sst5.com/readArticle.aspx?ArtID=1263\&SecID=19

عبد الله. تسنيم. (0 1 • ب). مواصفات القائد السياسي في الإسلام: عمر بن الخطاب أنموذجا.

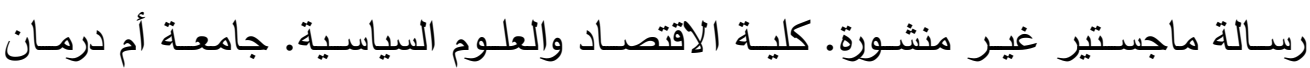

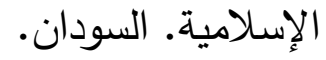

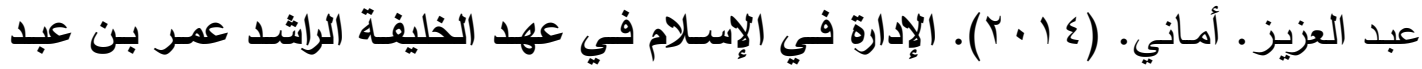

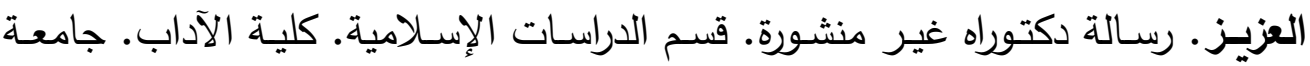

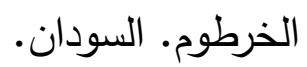

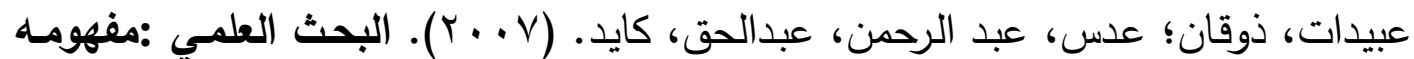
وأدواته وأساليبه .طو، . عمان، الأردن، دار أسامة.

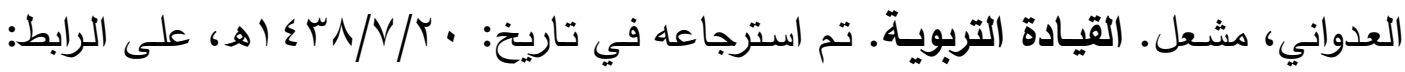
http://dr-meshaal.com/leadership 


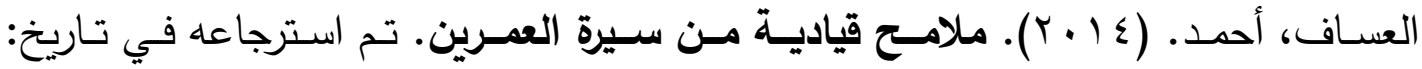

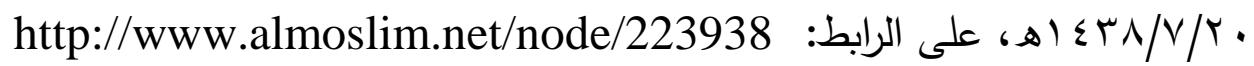

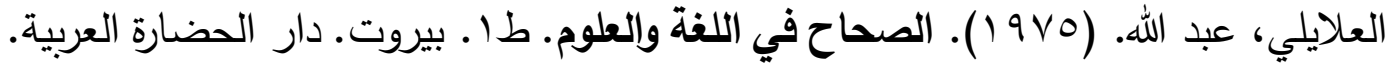
الغنام، متعب. (ب د). عمر بن عبد العزيز نموذج قيادي من التاريخ الإسلامي. ورقة عمل. كلية العلوم الاجتماعية، جامعة الإمام محمد بن سعود الإسلامية.

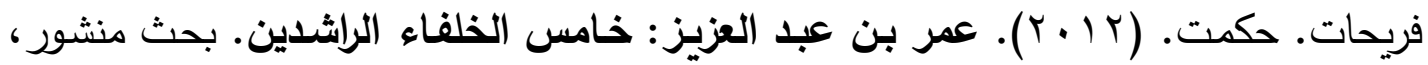

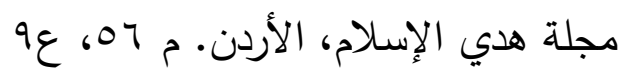

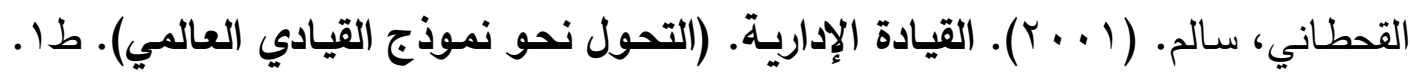

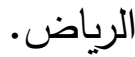

القحطاني، محمد. (997 (1). النموذج الإداري المستخلص من إدارة عمر بن عبد العزيز. رسالة ماجستير غير منشورة. معهد البحوث العلمية وإحياء التراث الإسلامي، جامعة أم المعرئ

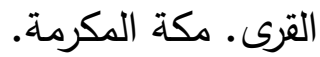
كوتر ، جون. (ب99 (1)). الفرق بين القيادة والإدارة. خلاصات كتب المدير والأعمال. القاهرة. الشركة العربية للإعلام العلمي(شعاع). الماوردي، علي. (7919 (). أدب الدنيا والدين. دار مكتبة الحياة.

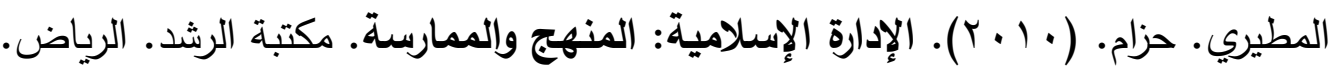

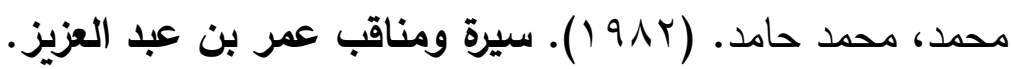

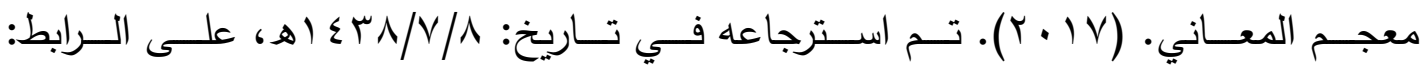
http://www.almaany.com

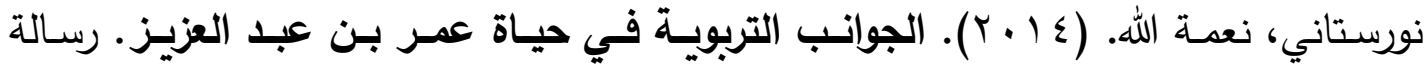

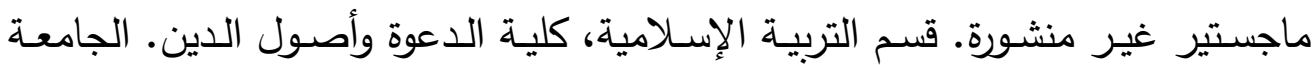
الإسلامية بالمدينة المنورة.

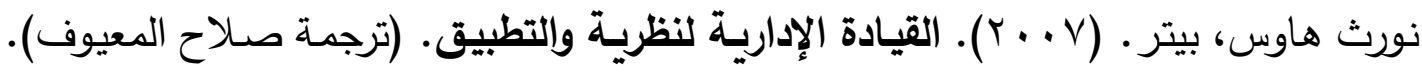

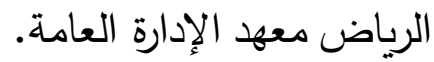

Yukl, G.A., 1989, Leadership organization. Englewood cliffs, Perntic Hall. 


\section{Abstract}

The study aimed to identify the concept of administrative leadership in Islamic thought, and the most important qualities of leadership that characterized Omar bin Abdul Aziz, and its leadership approach in its departments of the state. the study used the analytical descriptive approach, and the historical approach. The major findings of the study were the following the Islamic leadership has a lofty goal, it seeks to participate and education and characterized by a high degree of acceptance of criticism for the public interest. the personality of Omar bin Abdul Aziz is a leading figure, where he pursued a clear leadership approach, which reflected his wise policy and his justice.so, his approach to leadership becomes an example. and the period spent by Omar bin Abdul Aziz in power an important cultural period in the Islamic community, where the practical application of the Islamic approach to leadership has been applied in practice, planning and organization were carried out in his administration of the State. The recommendations of the study is emphasize the need to benefit from Omar Bin Abdul Aziz's approach to leadership and its applications in educational administration.

Keywords: Administrative Leadership, Omar bin Abdul Aziz. 